\title{
ARTICLE
}

Received 1 Oct 2013 | Accepted 6 May 2014 | Published 5 Jun $2014 \quad$ DOl: 10.1038/ncomms5063

\section{Intramuscular adipogenesis is inhibited by myo-endothelial progenitors with functioning Bmprla signalling}

Ping Huang ${ }^{1}$, Tim J. Schulz ${ }^{2, \dagger}$, Ariane Beauvais ${ }^{1, \dagger}$, Yu-Hua Tseng ${ }^{2}$ \& Emanuela Gussoni ${ }^{1}$

Developing human muscle contains inter-myofibre progenitors expressing Bmp-receptor 1a (Bmpr1a) and Myf5 that respond to stimulation with Bmp4. Here we ablate Bmprla in Myf5- and MyoD-expressing cells in vivo. Mutant mice reveal increased intramuscular fat and reduced myofibre size in selected muscles, or following muscle injury. Myo-endothelial progenitors are the most affected cell type: clonal studies demonstrate that ablation of Bmprla in myo-endothelial cells results in decreased myogenic activity, while adipogenic differentiation is significantly increased. Downstream phospho-Smad 1, 5, 8 signalling is also severely decreased in mutant myo-endothelial cells. Lineage tracing of endothelial cells using VE-cadherin ${ }^{C r e}$ driver failed to reveal a significant contribution of these cells to developing or injured skeletal muscle. Thus, myo-endothelial progenitors with functioning Bmprla signalling demonstrate myogenic potential, but their main function in vivo is to inhibit intramuscular adipogenesis, both through a cell-autonomous and a cell-cell interaction mechanism.

\footnotetext{
${ }^{1}$ Division of Genetics, Boston Children's Hospital, Boston, Massachusetts 02115, USA. ${ }^{2}$ Section on Integrative Physiology and Metabolism, Joslin Diabetes Center, Boston, Massachusetts 02115, USA. † Present addresses: Department of Adipocyte Development, German Institute of Human Nutrition PotsdamRehbrücke, 14558 Nuthetal, Germany (T.J.S.); Regenerative Medicine Program, Ottawa Hospital Research Institute, Ottawa, Ontario, Canada K1Y 4E9 (A.B.). Correspondence and requests for materials should be addressed to E.G. (email: gussoni@enders.tch.harvard.edu).
} 
S keletal muscle exhibits sustained regenerative capacity in response to acute injury or disease. This remarkable regenerative capacity is thought to be largely due to satellite cells, the tissue-specific stem cells located beneath the basal lamina of mature myofibres ${ }^{1-3}$. Quiescent satellite cells in adult muscle express the transcription factor Pax7, while their activation is marked by co-expression of Myf5 and $\mathrm{MyoD}^{4-7}$. Myf5 and MyoD can partially compensate for one another during development ${ }^{8-10}$, although they also have distinct functions ${ }^{11}$. Besides satellite cells, other progenitors with myogenic activity have been identified ${ }^{12}$. This heterogeneous group includes cells located interstitially between muscle fibres or tightly associated with the capillaries ${ }^{13-17}$. Despite accumulating evidence that inter-myofibre cells that do not express myogenic markers can adopt a myogenic fate ${ }^{16,18}$, their function in postnatal muscle remains poorly understood. Studies have indicated that during myogenic regeneration inter-cellular interactions occur between myogenic and fibro-adipogenic cells ${ }^{19-22}$, but the exact signals that regulate this process have not been elucidated. In addition, multipotential interstitial progenitors within skeletal muscle hypersensitive to Bmp signalling are likely responsible for heterotopic ossification observed in fibrodysplasia ossificans progressiva (FOP), but these cells do not derive from the endothelium ${ }^{23}$.

Our previous studies in human fetal skeletal muscle concluded that Bmp signalling is important for the proliferation of interstitial progenitors, which co-express Myf5 and Bmprla ${ }^{24}$. However, neither the myogenic differentiation potential of these progenitors in developing or adult muscle nor the consequences of altering Bmprla signalling in vivo are known.

In the present study, we ablated Bmprla signalling in cells expressing the myogenic markers $M y f 5$ or MyoD. Myf5 $5^{+/ C r e}$ : Bmprla $f / f$ mice were born runted and remained small throughout life, with several epaxial muscles (paraspinal, neck and trapezius) exhibiting severely decreased size, accompanied by increased intramuscular fat. Limb muscle injury with cardiotoxin (CTX) also led to significant accumulation of fat tissue in mutant mice of both genotypes. Analyses of wild-type and mutant muscles revealed that a subfraction of endothelial cells (Sca- ${ }^{\text {pos }} \mathrm{CD} 45$ ${ }^{\text {neg }} \mathrm{CD} 31^{\text {pos }}$ PDGFR $\alpha^{\text {neg }}$, named MECs) exhibits myogenic potential and suppresses the differentiation of intramuscular adipocytes when Bmprla signalling is unaffected. When Bmprla signalling is disrupted, MEC cells lose their myogenic differentiation potential and instead exhibit increased adipogenic potential. In addition, their ability to suppress intramuscular adipocytes is severely inhibited. Thus, myo-endothelial progenitors with functioning Bmprla signalling adopt a myogenic fate and act as suppressors of intramuscular fat formation. Bmp signalling in this subfraction of endothelial cells could act as a key regulator for balance between muscle and fat.

\section{Results}

Conditional ablation of Bmprla in Myf5 and MyoD progenitors. To study the role of Bmprla signalling in myogenic cells, Bmprla f/f mice ${ }^{25}$ were crossed with mice expressing Cre under the control of the Myf5 promoter $\left(\text { Myf5 } 5^{+/ C r e}\right)^{26}$. Myf5 $5^{+/ C r e}$ : Bmprlaf/f mice were born runted and remained significantly smaller than wild-type (WT) littermates throughout life (Fig. 1a). The body weight of $M y f 5^{+/ C r e}: B m p r 1 a^{f / f}$ conditional knockout (KO) mice was significantly reduced compared with WT littermates (Fig. 1b). Gross examination revealed that the dorsal skeletal muscles from $\mathrm{KO}$ mice were smaller than that in WT mice (Fig. 1c). Normalization of the individual muscle weight to the total body weight confirmed significant difference in size of the mutant epaxial muscles, including the paraspinal and trapezius (Fig. 1d). To examine whether the myofibre number and/or size was altered in conditionally ablated Bmprla mutant muscles, cross-sections of paraspinal and trapezius muscles from WT and KO animals were compared at the same anatomical position to ensure that any difference observed was not due to the plane of sectioning. The transverse area of the entire paraspinal muscle bundle was notably smaller in $M y f 5^{+/ C r e}:$ Bmpr $1 a^{f / f}$ mice than in WT mice (Fig. 1e), with a significantly lower number of myofibres in Myf5 ${ }^{+/ C r e}:$ Bmprla ${ }^{f / f}$ muscles (Fig. 1f). Reduced myofibre size was observed in both paraspinal and trapezius mutant muscles (Fig. 1h,j), accompanied by fat accumulation (Fig. 1g,i, yellow arrows), which was confirmed by Oil red $\mathrm{O}$ staining (Supplementary Fig. 1A) and by the increased expression of the adipocyte marker fatty acid synthase (Fasn, Supplementary Fig. 1D). In contrast, the tibialis anterior (TA) and gastrocnemius (GA) muscles did not reveal significant differences in myofibre size (Supplementary Fig. 1E,F,H,I,K). Since Myf5 ${ }^{\text {pos }}$ myogenic progenitors contribute mostly to epaxial muscles, such as paraspinal, intercostal and trapezius ${ }^{27}$, while MyoD ${ }^{\text {pos }}$ progenitors contribute to hypaxial muscles, including limb muscles ${ }^{28}$, we asked whether Bmprla function might be linked to both myogenic cell lineages. A second knockout mouse model was generated by crossing $M y o D^{+/ i C r e}$ (ref. 29) to Bmprla f/f mice. $M y o D^{+/ i C r e}: B m p r 1 a^{f / f}$ mice had the same body weight as control mice and the hypaxial muscles (TA and GA) revealed no significant differences compared with controls both histologically and in myofibre cross-sectional area (Supplementary Fig. 1G,J,K). The paraspinal muscle also appeared unaffected in $M y o D^{+/ i C r e}:$ Bmprlaf/f mice (Supplementary Fig. 1C). Bmprla expression was analysed via quantitative RT-PCR using 5-6 animals per cohort, and it was significantly reduced in nearly all $M y f 5^{+/ C r e}: B m p r 1 a^{f / f}$ skeletal muscles examined, except for the diaphragm (Supplementary Fig. 1M), suggesting that development of the diaphragm muscle might differ from other skeletal muscles, which is not surprising given its complex anatomical structure $^{30}$. Similarly, expression of Bmprla mRNA was significantly decreased in muscles from $M y o D^{+/ i C r e}: B m p r l a f / f$ mice (Supplementary Fig. 1N). Thus, while expression of Bmpr1a was effectively reduced in both Myf5 and MyoD progenitors, $M y f 5^{+/ C r e}:$ Bmprla ${ }^{f / f}$ mice exhibited more obvious abnormalities, suggesting that Bmprla function might be more prominent in Myf5 progenitors.

Muscle regeneration in mutant mice leads to increased fat. Bmprla mRNA is transiently upregulated from day 3 to day 5 post-cardiotoxin (CTX) injury in WT mice (Fig. 2a), a time when myogenic progenitors are activated for repair ${ }^{31,32}$. The muscle regenerative capacity of Bmprlaf/f (control), Myf5 ${ }^{+/ C r e}: B m p r l a f / f$ and $M y o D^{+/ i C r e}: B m p r l a f / f$ mice were assayed in parallel. After 7 days, centrally nucleated myofibres were seen in all genotypes, indicating ongoing regeneration; however, mutant mice displayed increased fat infiltration, as confirmed by Oil Red $\mathrm{O}$ staining (Fig. 2b). The mRNA levels of the adipogenic transcription factor peroxisome proliferator-activated receptor $\gamma(\operatorname{PPAR} \gamma)$ and the fatty acid-binding protein 4 (FABP4, also known as aP2) were significantly elevated in injured mutant muscle (Fig. 2c). In addition, regenerated myofibres were significantly smaller in $M y f 5^{+/ C r e}: B m p r 1 a^{f / f}$ and $M y o D^{+/ i C r e}: B m p r 1 a^{f / f}$ mice compared with controls by $t$-test $(P<0.05)$ (Fig. $2 \mathrm{~d})$. At day 18 after CTX injection, mutant muscles still exhibited a significant amount of fat accumulation, and the diameter of regenerated myofibres was $15 \%$ smaller in $M y f 5^{+/ C r e}:$ Bmprla ${ }^{f / f}$ mice compared with controls $(P<0.01)$ (Fig. 2e). Similar results were seen in injured GA muscle. Recent studies have reported that TGF $\beta$ signalling can affect myofibre size through ALK4 and ALK5 type I activin 

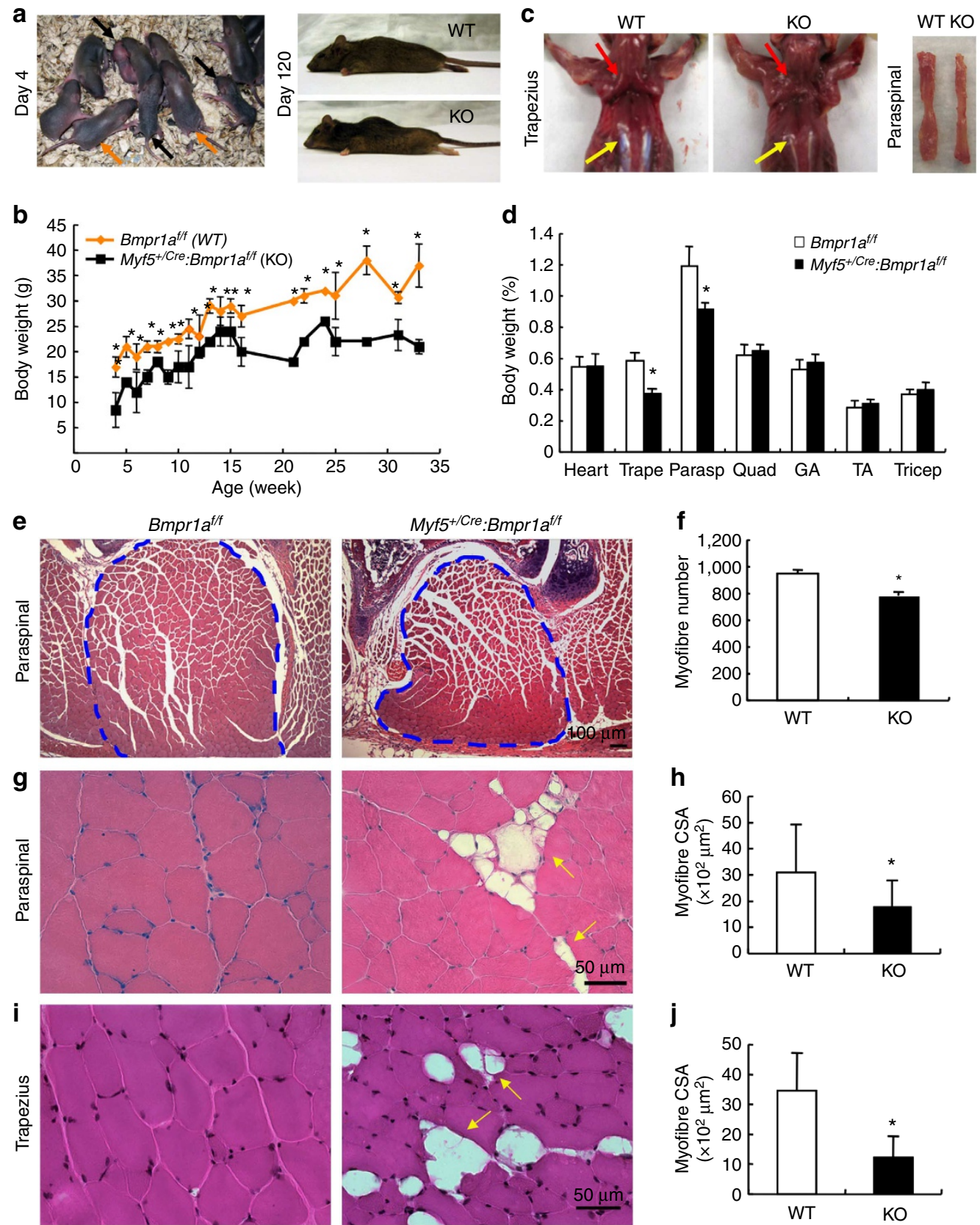

Figure 1 | Myf5 ${ }^{+} / \mathrm{Cre}_{\mathbf{i}} \mathrm{Bmpr1a}^{\mathrm{f} / f}$ mice are born runted with small epaxial muscles. (a,b) Body size and weight of $\mathrm{Myf5}+/ \mathrm{Cre}: \mathrm{Bmpr} 1 \mathrm{a}^{f / f}(\mathrm{KO})$ mice compared with Bmpriafff (WT) littermates. Adult KO mice exhibit severe kyphosis, indicating the weakness of the dorsal muscles. Black arrows point to KO mice, orange arrows to WT littermates. (b) Body weight comparison was derived from female mice and data are presented as mean $\pm \mathrm{s}$.d. by $t$-test ( $n=6$; ${ }^{\star} P<0.05$ ). Similar results were seen with male mice (Supplementary Fig. 1L). (c) Trapezius (red arrow) and paraspinal (yellow arrow) muscles in WT and KO littermate mice. (d) Normalization of tissue masses with total body weight $\left(n=3 ;{ }^{\star} P<0.05\right)$. Trape: trapezius; Parasp: paraspinal; GA: gastrocnemius; TA: tibialis anterior. (e) H\&E staining of transverse sections of paraspinal muscle bundle (outlined by the blue dotted line) in Bmpria ${ }^{f / f}(\mathrm{WT})$ and

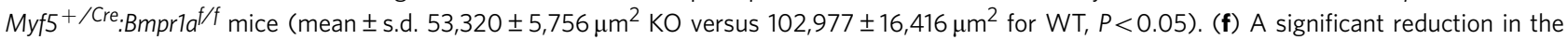
number of myofibres was observed in mutant animals (mean \pm s.d. $784 \pm 52$ in Myf5 ${ }^{+/ C r e}:$ Bmprlat/f versus $949 \pm 48$ in $W T, t$-test ${ }^{\star} P<0.05, n=3$ ). $(\mathbf{g}, \mathbf{i})$ Presence of adipocytes (yellow arrows) and $(\mathbf{h}, \mathbf{j})$ reduced cross-sectional area (CSA) were also seen in mutant paraspinal and trapezius muscles, respectively $\left(n=3 ;{ }^{\star} P<0.05\right)$. Error bars in $(\mathbf{f}, \mathbf{h}, \mathbf{j})$ represent the s.d.

receptors (which signal via pSmad 2,4$)^{33}$. In addition, Bmp signalling through pSmad 1,5,8 can affect myofibres size via downstream signalling through $\mathrm{mTOR}^{34}$. Given that Bmprla is known to signal via pSmad $1,5,8$ (ref. 35), we examined phosphorylation of Smad1/5/8 and Smad2 in uninjured and injured muscles from WT and Myf5 $5^{+/ C r e}: B m p r l a a^{f / f}(\mathrm{KO})$ mice (Supplementary Fig. 2A). Phospho-smad1/5/8 levels were slightly reduced in epaxial muscles as well as in cardiotoxin-injured TA muscles from $\mathrm{KO}$ mice. In contrast, pSmad2 expression was similar between WT and KO muscles, suggesting ablation of Bmprla does not affect signalling through pSmad2.

To determine whether the reduced regenerative capacity of $M y f 5^{+/ C r e}:$ Bmprlaf/f muscle was due to a decreased number of satellite cells, the number of Pax ${ }^{\text {pos }}$ cells was assessed by 

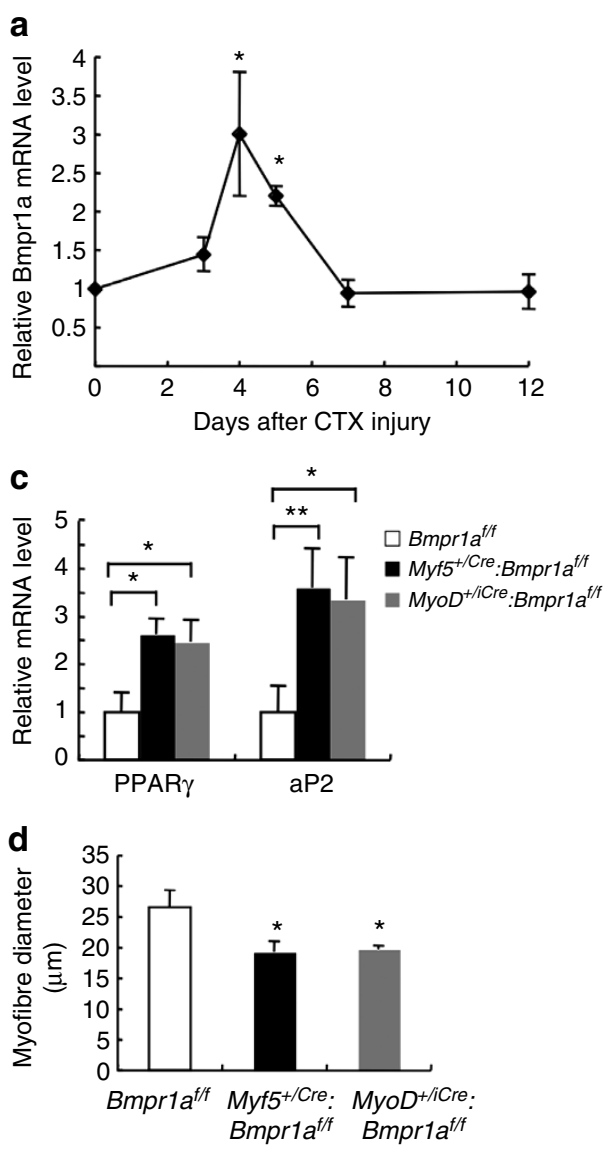

b
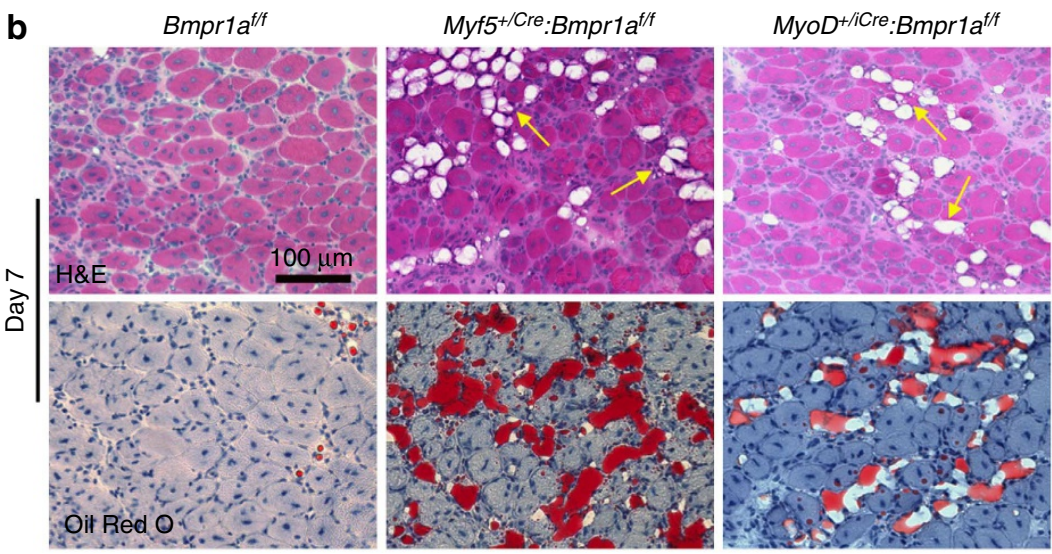

\section{e}
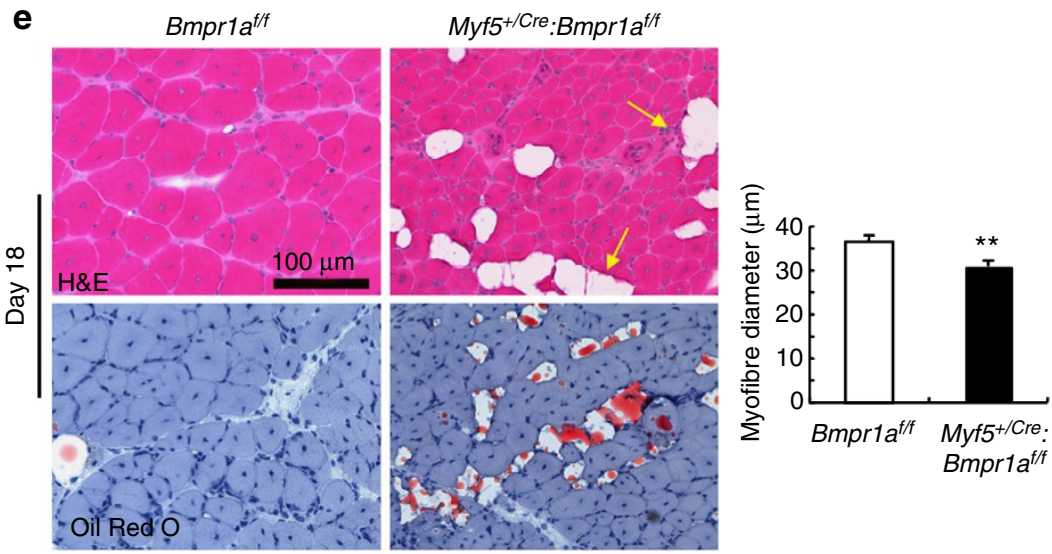

Figure 2 | Increased fat infiltration and decreased myofibre size in regenerating mutant muscle. (a) Transient upregulation of Bmpr1a mRNA in regenerating TA muscle of WT mice following CTX injury. Results are shown as mean \pm s.d. $\left(n=3,{ }^{\star} P<0.05\right)$. (b) H\&E staining of cross-sections of TA muscles 7 days after CTX injury. Lipid accumulation in mutant mice (yellow arrows) was confirmed by Oil Red O staining. (c) Expression of the adipogenic transcription factor PPAR $\gamma$ and the mature adipocyte marker aP2 were assessed by real-time qRT-PCR 4 days post-injury. Both were significantly increased in regenerating muscle from mutant mice $\left(n=3-4 ;{ }^{\star} P<0.05 ;{ }^{\star \star} P<0.01\right.$. Error bars define the s.d. value). (d) Average myofibre diameter was significantly greater in regenerating TA muscle of control Bmpriat/f mice $(26.6 \pm 2.8 \mu \mathrm{m})$ compared with $\mathrm{Myf5}+/ \mathrm{Cre}: \mathrm{Bmpria} \mathrm{f}^{f / f}(19.3 \pm 1.8 \mu \mathrm{m})$ and $M y o D^{+/ C r e}: B m p r 1 a^{f / f}$ mice $(19.7 \pm 0.6 \mu \mathrm{m}) 7$ days following CTX injury. Data were averaged $(n=4$ mice/group) and expressed as mean \pm s.d. $\left({ }^{\star} P<0.05\right)$. (e) H\&E (upper panels) and oil-red O staining (lower panels) of regenerating WT and KO tibialis anterior (TA) muscle 18 days following CTX injury. Fat accumulation (indicated by arrows) is still observed, as is a significantly reduced myofibre size in mutant mice $(30.9 \pm 1.3 \mu \mathrm{m}$ versus $36.5 \pm 1.4 \mu \mathrm{m}$ for control $)\left(n=3,{ }^{\star \star} P<0.01\right)$.

immunohistochemistry on cross-sections of TA muscles either uninjured or 7 days post CTX injury (Supplementary Fig. 2B, arrows). No significant differences in the number of Pax $7^{\text {pos }}$ cells were seen between the genotypes (Supplementary Fig. 2C). To confirm these results, Pax7 expression was examined via quantitative real-time RT-PCR and western blot (Supplementary Fig. 2D). Again, no significant differences were observed between control and mutant mice in either uninjured or regenerating muscle.

Mutant myo-endothelial cells lose myogenic potential. To identify the cell type(s) responsible for the increased fat accumulation in mutant muscle, multiple cell fractions, including satellite cells (SCs); endothelial and myo-endothelial cells (MECs); and adipogenic progenitors (APs), were isolated by FACS as outlined in Supplementary Fig. 3. Satellite cells were isolated as Sca- $1^{\text {neg }} \mathrm{CD} 45^{\text {neg }} \mathrm{CD} 31^{\text {neg }} \mathrm{CD} 106^{\text {pos }}$ cell fraction (Supplementary Fig. 3G), as previously described ${ }^{36,37}$. Endothelial and myo-endothelial cells were isolated as $\mathrm{Sca}-1^{\text {pos }} \mathrm{CD} 45^{\text {neg }}$ $\mathrm{CD} 31^{\text {pos }}{ }^{\text {PDGFR }} \alpha^{\text {neg }}$ cells (Supplementary Fig. $3 \mathrm{H}$ ). Adipogenic progenitors were purified as $\mathrm{Sca}-1^{\mathrm{pos}} \mathrm{CD} 45^{\text {neg }} \mathrm{CD} 31^{\text {neg }}$ cells, which were also $>95 \% \mathrm{PDGFR}^{\mathrm{pos}}$ (Supplementary Fig. 3F,I). To validate the purity of freshly isolated SCs, MECs and APs, the purified cell fractions were assessed for expression of Sca-1 and CD31 following cytospin (Supplementary Fig. 4). As expected, all MECs were Sca- $1^{\text {pos }} \mathrm{CD} 31^{\text {pos }}$, SCs were Sca- $1^{\text {neg }} \mathrm{CD} 31^{\text {neg }}$, while APs were Sca- $1^{\text {pos }} \mathrm{CD} 31^{\text {neg }}$, suggesting minimal or no overlap among these cell groups.

Given the possibility that MECs could overlap with other cell fractions previously described, such as mesoangioblasts and pericytes $^{38,14,17}$, PICs ${ }^{16,39,40}$ and beta-4 integrin ${ }^{\text {pos }}$ ( $\beta 4$-ITG) interstitial myogenic progenitors ${ }^{41}$, expression of additional markers was tested in MECs, APs and SCs (Supplementary Fig. 5). By FACS analysis, a small fraction of MECs expressed $\beta 4$-ITG $(\sim 10 \%$, Supplementary Fig. $5 \mathrm{~A})$, while by qRT/PCR MECs expressed PDGFR $\beta$, NG2 and PW1 at lower levels as compared with APs and SCs (Supplementary Fig. 5B). Semiquantitative RT/PCR followed by gel separation of the PCR products confirmed the presence of PDGFR $\beta$ expression in MECs, while no bands were seen following amplification of NG2 or PW1 mRNAs in MECs (Supplementary Fig. 5C). Of note, SCs 
expressed PW1 mRNA, a result in agreement with previously published data ${ }^{40}$. These results were confirmed by antibody staining on cytospins of freshly isolated MECs. Within a total 500-700 MECs analysed, 5.3\% were positive for PDGFR $\beta, 0.6 \%$ were positive for NG2 and $0.5 \%$ were positive for smooth muscle actin (SMA) (Supplementary Fig. 5D,E).
To study the in vitro differentiation potential of SCs, MECs and APs, the cell fractions were isolated in parallel from control and $M y f 5^{+/ C r e}: B m p r 1 a^{f / f}$ mice and cultured in conditions that favour myogenic or adipogenic differentiation (Fig. 3). SCs isolated from WT and mutant mice differentiated robustly into myotubes, under either myogenic (Fig. 3a,b) or adipogenic differentiation
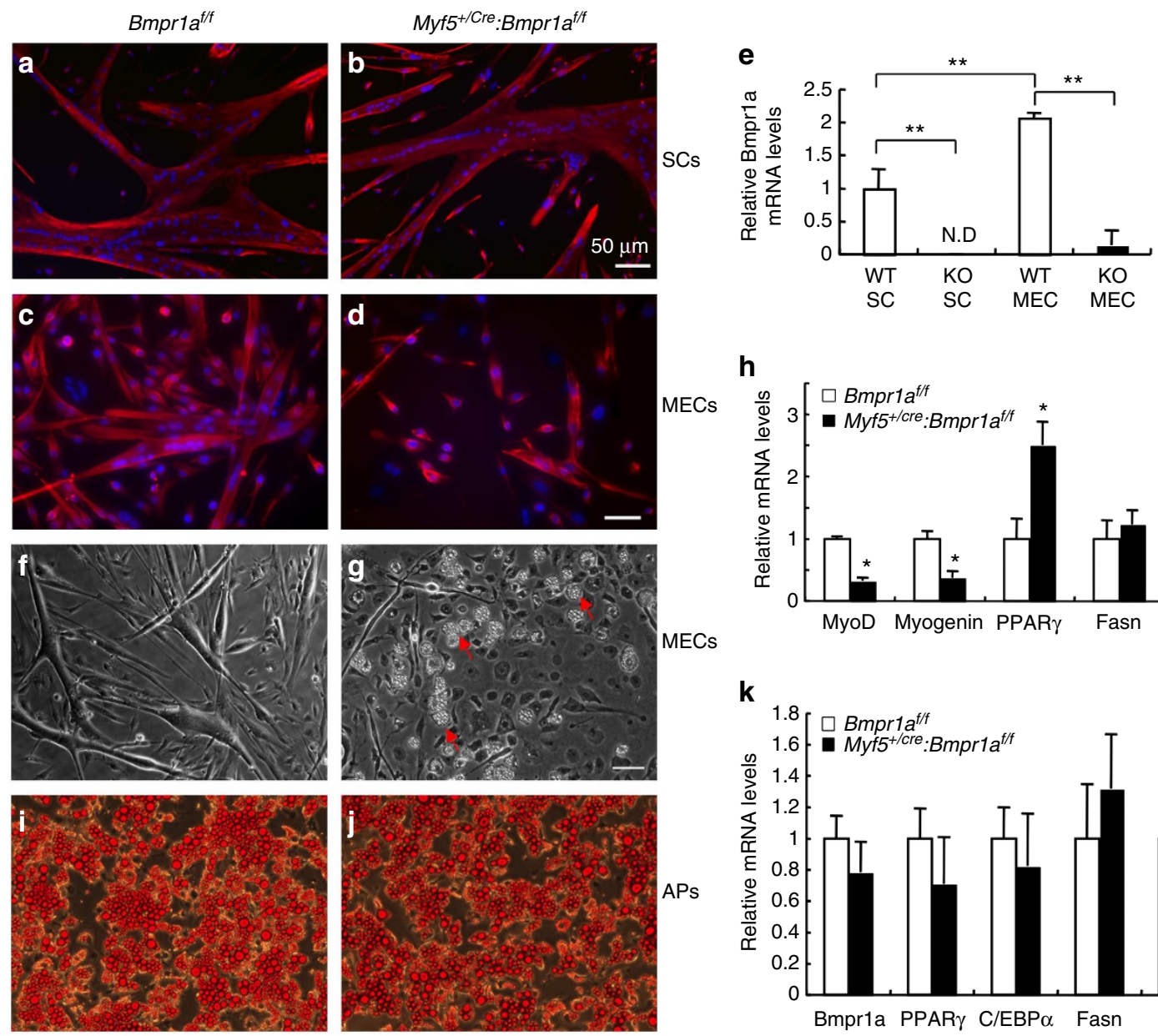

\section{h}

MECs
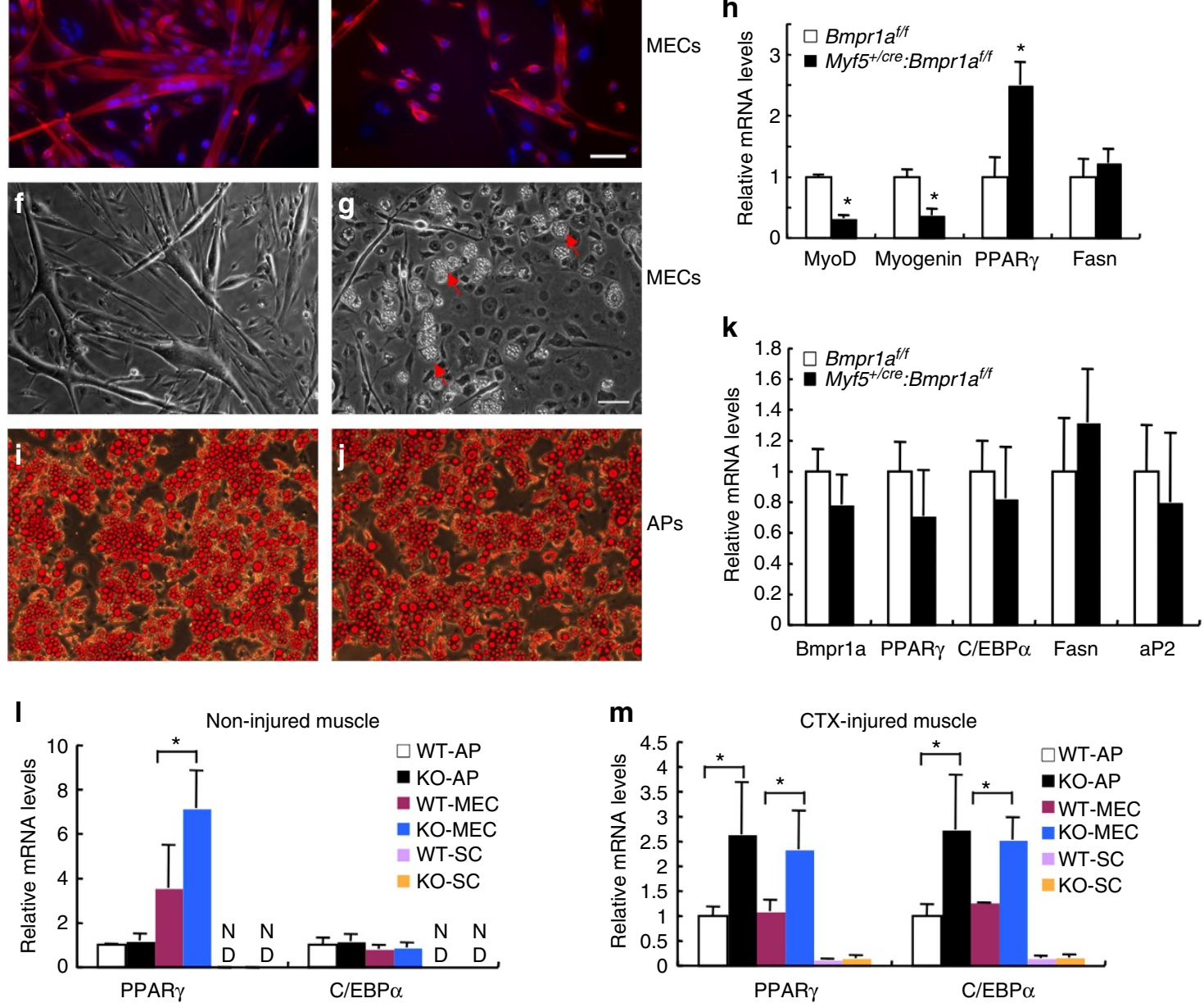

PPAR $\gamma$

$\mathrm{C} / \mathrm{EBP} \alpha$

Figure 3 | Mutant MECs adopt an adipogenic fate. Different cell populations were separated by FACS from pooled epaxial and hypaxial muscles.

$(\mathbf{a}, \mathbf{b})$ Desmin immunostaining (red) of satellite cells differentiated for 4 days in myogenic differentiation medium shows robust formation of myotubes in

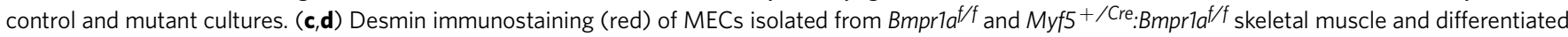
for 4 days. Nuclei were stained with DAPI (blue). (e) Bmprla mRNA levels in SCs and MECs derived from Bmpr1at/f (WT) and Myf5 $+/ C r e: B m p r 1 a^{f / f}$ (KO) muscle. Results are shown as mean \pm s.d. $\left(n=3,{ }^{\star \star} P<0.01\right)$. ND, non-detectable. (f,g) MECs from Bmpria ${ }^{f / f}$ and $M y f 5^{+/ C r e}: B m p r 1 a^{f / f}$ skeletal muscle differentiated in adipogenic medium. Control MECs form myotubes (f), while mutant MECs adopt an adipogenic fate (g). (h) mRNA levels for myogenic and adipogenic markers in MECs derived from Bmpriat/f and Myf5 $+/$ Cre: Bmpriaf/f muscle. Results are shown as mean $\pm \mathrm{s} . \mathbf{d}$. $\left(n=3,{ }^{\star} P<0.05\right)$. (i,j) Sorted AP cells from Bmpr1a $a^{f / f}$ and Myf5 $+/ C r e: B m p r 1 a a^{f / f}$ muscle induced to differentiate into adipocytes for 12 days before Oil Red O staining. (k) RNA isolated from cultured AP cells and analyzed for expression of Bmprla and adipogenic markers by real-time qRT-PCR. No differences were seen between control and mutant cells. Results are shown as mean \pm s.d. $(n=3)$. $(\mathbf{I}, \mathbf{m})$ APs, SCs and MECs freshly isolated from non-injured $(\mathbf{I})$ or CTX-injured muscle 4 days post-injury ( $\mathbf{m})$ in control and mutant mice were assayed for adipogenic marker PPAR $\gamma$ and C/EBP $\alpha$ mRNA expression by quantitative real time RT/PCR. WT: Bmpria ${ }^{f / f}$; KO: Myf5 ${ }^{+/ C r e}: B m p r 7 a^{f / f}$. Results are shown as mean \pm s.d. $(n=3)$. Error bars indicate s.d., $n=3,{ }^{\star} P<0.05$ by $t$-test. 
condition (Supplementary Fig. 6A), with no differences detected between the genotypes despite the fact that Bmprla expression was severely decreased in mutant SCs and MECs (Fig. 3e). MECs are a mixed population containing both endothelial and myoendothelial cells, and a subfraction of MECs attach to the tissue culture plates when cultured. These cultured MECs from WT mice differentiated consistently into myotubes, regardless of whether they were cultured in myogenic (Fig. 3c) or adipogenic differentiation conditions (Fig. 3f), suggesting MECs can adopt a myogenic fate in vitro. In contrast, MECs from mutant mice with severely reduced Bmprla expression showed decreased myogenic differentiation potential (Fig. 3d) and presence of mature adipocytes when differentiated in adipogenic medium (Fig. 3g). These findings were confirmed by quantitative real-time RT-PCR, which demonstrated increased mRNA expression of $\operatorname{PPAR} \gamma$ and decreased expression of MyoD and myogenin in mutant MECs compared with control (Fig. 3h). Given the increased fat accumulation in muscles with altered Bmprla signalling, AP cells from control and $M y f 5^{+/ C r e}: B m p r 1 a^{f / f}$ muscle were also analysed in parallel to determine possible abnormalities in this adipogenic progenitor fraction. We found that mutant AP cells displayed similar adipogenic differentiation potential to control AP cells (Fig. 3i,j). In addition, no decreased Bmprla expression was detected in mutant APs (Fig. 3k), as expected by the notion that intramuscular adipogenic cells derive from Myf5negative lineage progenitors ${ }^{19,21,42}$. Accordingly, expression of early and mature adipocyte markers was also indistinguishable between control and mutant APs (Fig. 3k). Collectively, these data suggest that ablation of Bmprla signalling affects MECs differentiation: expression of Bmprla is necessary for the commitment of MECs to the myogenic lineage, while its depletion results in increased adipogenic potential of these cells.

To prove that the adipogenic potential of MECs in mutant mice is not due to an adaptation to the in vitro culture conditions and that MECs with disrupted Bmprla signalling express adipogenic transcription factors in vivo, MECs, APs and SCs were isolated in parallel from control and $M y f 5^{+/ C r e}: B m p r 1 a^{f / f}$ mice from uninjured or CTX-injured muscles (Fig. 31,m). Freshly isolated cells were analysed by real-time PCR for expression of early $(\mathrm{PPAR} \gamma)$ and mature $(\mathrm{C} / \mathrm{EBP} \alpha$, CCAAT-enhancer-binding protein $\alpha$ ) adipogenic markers. In MECs extracted from noninjured muscle, PPAR $\gamma$ expression was significantly elevated in mutant MECs compared with control MECs. Overall, PPAR $\gamma$ expression was higher in MECs compared with APs from either control or mutant mice (Fig. 31). In contrast, satellite cells from either control or mutant mice did not express detectable levels of $\mathrm{PPAR} \gamma$ or $\mathrm{C} / \mathrm{EBP} \alpha$ (Fig. 3l). These results demonstrate that MECs have intrinsic adipogenic potential. Following cardiotoxin injury, both $\operatorname{PPAR} \gamma$ and $\mathrm{C} / \mathrm{EBP} \alpha$ expression levels were significantly elevated in MECs and APs from mutant mice compared with controls, while the level of expression in satellite cells remained very low (Fig. $3 \mathrm{~m}$ ). These data are in agreement with the increased adipocyte accumulation in mutant regenerating muscle, and it supports the hypothesis that both APs and MECs can contribute to adipocyte formation in regenerating muscles lacking Bmprla.

MECs are bipotent and inhibit differentiation of adipocytes. To study whether MECs gain adipogenic differentiation potential following loss of Bmprla expression, MECs extracted from $B m p r 1 a^{f / f}$ muscles were treated with Cre-expressing adenovirus (Adeno $^{\mathrm{Cre}}$ ) to delete the floxed Bmprla gene. Control Bmprlaf/f MECs robustly differentiated into myotubes even when cultured in adipogenic medium (Fig. 4a), while Bmprla $a^{f / f}$ MECs treated with Adeno ${ }^{\text {Cre }}$ showed nearly complete inhibition of myotube formation and induction of adipocyte formation (Fig. 4b, red arrows). Real-time RT/PCR analysis revealed that Bmprla expression was completely depleted in the Adeno ${ }^{\mathrm{Cre}}$-treated cultures, accompanied by a severe reduction in MyoD and myogenin expression, while the expression of the pre-adipocyte marker PPAR $\gamma$ was significantly increased (Fig. 4c). Expression of the mature adipocyte markers Fasn and aP2, however, did not increase, suggesting that under these conditions the majority of the Adeno ${ }^{C r e}$-treated cells are immature adipocytes. To determine at the clonal level whether MECs can adopt two cell fates (myogenic or adipogenic), MECs from Bmprlat/f muscles were treated with or without Adeno ${ }^{\text {Cre }}$ virus and individual cells from both populations were sorted into single wells of 96-well plates by FACS. Single cells were allowed to expand in growth medium for 10-12 days, followed by adipogenic differentiation. For untreated MECs, all derived clones were myogenic, which formed myotubes as determined by co-expression of desmin and MyoD (Fig. $4 \mathrm{~d}, \mathrm{~g}$ ). In contrast, only $20.8 \%$ of MEC clones were myogenic following Bmprla ablation, whereas the majority $(66.7 \%)$ was adipogenic, as confirmed by expression of perilipin (Fig. 4e,g) or PPAR $\gamma$ (Supplementary Fig. 6B). In addition, $12.5 \%$ of Adeno ${ }^{\text {Cre }}$-treated MEC clones expressed desmin and perilipin (Fig. 4f,g), further supporting that MECs can adopt dual cell fate.

In addition to the evidence that MECs themselves could contribute to the fat accumulation observed in mutant mice, the possibility that interactions between MECs and APs promote intramuscular AP cells to differentiate at the expense of muscle was also examined. AP cells were isolated from $\beta$-actin-EGFP

Figure 4 I Ablation of Bmpr1a expression in MECs results in increased adipogenesis. (a,b) Bmprla $f / f$ MECs treated with (b) or without (a) Adeno $\mathrm{Cre}$ were induced to differentiate in adipogenic medium $(n=3)$. (a) MECs with functional Bmprla signalling form myotubes even when cultured in adipogenic medium. (b) MECs treated with AdenoCre exhibit decreased myotube formation and show presence of mature fat cells (red arrows). (c) Expressions of myogenic and adipogenic markers were assessed in MEC cultures treated or non-treated with Adeno ${ }^{C r e}$. MyoG $=$ myogenin. Results are shown as mean \pm s.d. $\left(n=3,{ }^{\star}=P<0.05\right)$. (d-f) Examples of myogenic (d), adipogenic (e) and dual potential (f) clones derived from four 96 -well plates seeded with single untreated or Adeno ${ }^{C r e}$-treated MECs assayed by immunofluorescence staining. The clonal efficiency was $\sim 19 \%$ for untreated cells and $13 \%$ for Adeno ${ }^{C r e}$ treated cells, respectively. Adipogenic cells express lipid-droplet-associated protein perilipin, while myogenic cells express desmin. Scale bar, $50 \mu \mathrm{m}$. (g) Wild-type MECs gave rise to myogenic clones only, while MEC clones that were treated with Adeno ${ }^{\text {Cre }}$ gave rise to mainly adipogenic clones, with significantly less myogenic clones and clones containing cells both myogenic and adipogenic. (h,i) AP cells isolated from $\beta$-actin-EGFP transgenic mice (green) were cultured alone (GFP-AP) or co-cultured with MECs derived from Bmpr1af/f (WT) or Myf5 $+/ C r e: B m p r 1 a^{f / f}(\mathrm{KO})$ muscle at the ratio of 1: 0.5 , unless otherwise stated. Data are presented as mean \pm s.d. $\left(n=3,{ }^{\star \star} P<0.01 ;{ }^{\#} P<0.001\right)$. Co-cultures were incubated in $M C D B$ growth medium for 4 days, followed by induction of adipogenic differentiation for 9 days; red arrows indicate adipocytes. Oil red $O$ staining was used to confirm the presence of mature adipocytes in the co-cultures. Scale bar, $50 \mu \mathrm{m}$. (j) Expression of early and late adipocyte markers was assessed by qRT-PCR in MEC co-cultures. Data are presented as mean $\pm \mathrm{s}$.d. $\left(n=3,{ }^{\star} P<0.05\right.$; $\left.{ }^{\star \star} P<0.01\right)$. (k) Adipocytes were cultured alone in control differentiation medium (control) or exposed to conditioned medium (CM) derived from WT- or KO-MEC cultures. No differences in expression of adipogenic markers were seen under these conditions, suggesting that the inhibition in AP-cell differentiation detected in the co-cultures is due to cell-cell contact between MECs and APs, rather than via inhibitory soluble factor(s). Error bars represent s.d., $n=3$. 
transgenic mice and cultured alone or co-seeded with different numbers of MECs from control Bmprla $a^{f / f}$ mice. In contrast to the single culture of APs, adipogenic differentiation was markedly inhibited when GFP ${ }^{\text {os }}$ APs were co-cultured with WT-MECs and the degree of inhibition positively correlated with the number of MECs added (Fig. 4h,i). In contrast, when MECs from $M y f 5^{+/ C r e}: B m p r 1 a^{f / f}$ mice were co-cultured with GFP ${ }^{\text {pos }}$ AP cells, inhibition of adipogenic differentiation was less obvious (Fig. 4h)
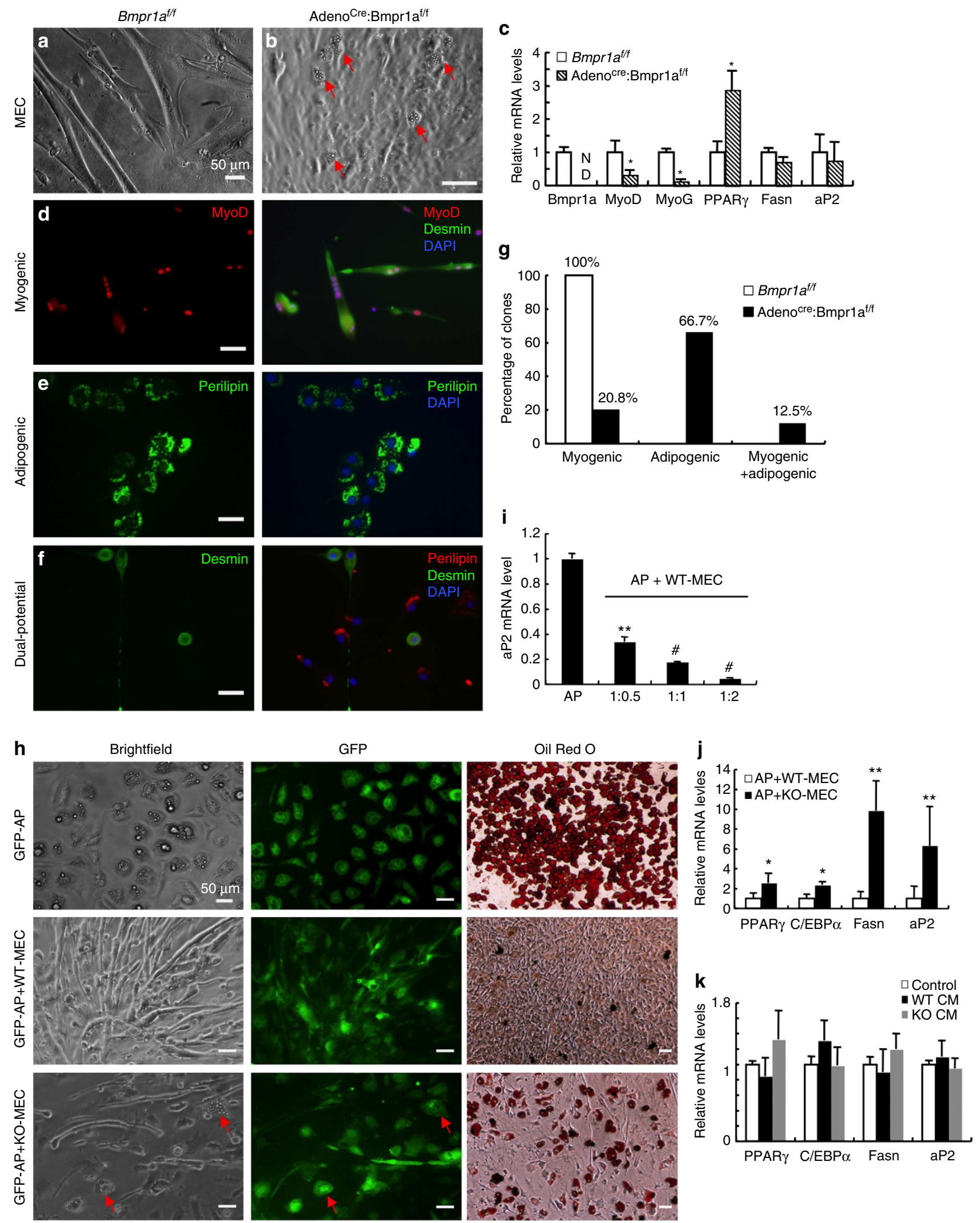
and expression of mature adipogenic markers was strongly upregulated as compared with co-culture with wild-type MECs (Fig. 4j). To test whether this inhibition is mediated by secreted/ soluble factors, APs were cultured in conditioned medium from WT- or KO-MECs. Inhibition of adipogenesis was not observed under these conditions (Fig. 4K). Collectively, these studies support the conclusion that MECs with functional Bmprla signalling exert an inhibitory effect on adipocyte differentiation, which is likely mediated by cell-cell contact.

Reduced proliferation and pSmad signalling in mutant MECs. Activation of Bmprla signalling is mediated through phosphorylation of Smad $1,5,8(\operatorname{Smad1} / 5 / 8)$ proteins $^{35}$. To determine whether Bmp signalling was affected downstream of Bmprla expression in mutant mice, phospho-Smad (pSmad1/5/8) activation under basal conditions and following stimulation with Bmp4 was assessed in SCs and MECs. pSmad signalling was decreased in epaxial SCs from $M y f 5^{+/ C r e}: B m p r 1 a^{f / f}$ mice under basal conditions and following stimulation with Bmp4, but not from $M y o D^{+/ i C r e}: B m p r 1 a^{f / f}$ mice (Fig. 5a). In contrast, limb SCs from either $M y f 5^{+/ C r e}: B m p r 1 a^{f / f}$ or $M y o D^{+/ i C r e}: B m p r 1 a^{f / f}$ mice did not show any significant change in pSmad signalling (Fig. 5b). Accordingly, SCs from the epaxial trapezius and paraspinal muscles of $M y f 5^{+/ C r e}: B m p r 1 a^{f / f}$ mice proliferated less efficiently than wild-type SCs, whereas SCs extracted from limb muscles were unaffected (Fig. 5c). SCs derived from MyoD ${ }^{+/ i C r e}: B m p r 1 a^{f / f}$ mice exhibited either increased or similar proliferation capacity to control SCs, regardless of whether they were derived from epaxial or hypaxial (limb) muscles (Fig. 5d). To explain why limb SCs were not affected following Bmprla ablation, the expression of two additional Bmp type I receptors, Bmprlb and activinreceptor like kinase 2 (Alk2), which could compensate for Bmprla decreased expression, was examined. Bmprlb mRNA expression levels revealed a $2.6 \pm 0.8$-fold increase in $\mathrm{KO}$ limb SCs compared with control SCs, while Alk2 expression was not changed (Fig. 5e). In contrast, epaxial SCs did not show compensatory upregulation of Bmpr1b or Alk2 expression (Fig. 5f).

Mutant MECs from Myf5 $5^{+/ C r e}: B m p r 1 a^{f / f}$ and $M y o D^{+/ i C r e}$ : Bmprlaf/f mice were also analysed for pSmad1/5/8 activation compared with control MECs. A significant reduction of active $\mathrm{pSmad}$ was seen in MECs from both Myf5 $5^{+/ C r e}:$ Bmprla f/f and $M y o D^{+/ i C r e}:$ Bmprlaf/f mice under basal conditions (Fig. $5 \mathrm{~g}$ ). In addition, when cells were stimulated with Bmp4, pSmad1/5/8 levels increased in control $\mathrm{C} 2 \mathrm{C} 12$ and WT MECs, but remained significantly lower in mutant cells (Fig. 5g). Mutant MECs from both limb and epaxial muscles also displayed substantially reduced proliferative capacity compared with control cells in both models (Fig. 5h,i). Collectively, these data support the conclusion that Bmprla signalling is important in MECs, which proliferate poorly when pSmad signalling is compromised. Moreover, epaxial SCs appear also to be affected by ablation of Bmprla, which may account for the reduced myofibre size in epaxial muscles of $M y f 5^{+/ C r e}: B m p r 1 a^{f / f}$ mice. In contrast, genetic ablation of Bmprla in limb satellite cells is compensated by upregulation of Bmpr1b.

MECs show myogenic potential in vitro and in vivo. To examine the localization of MECs in vivo, muscle tissue sections were co-stained for Sca-1, CD31 and laminin, which revealed the presence of two subtypes of Sca- $1^{\text {pos }} \mathrm{CD} 31^{\text {pos }}$ cells (Fig. 6). The first one is surrounded by its own laminin staining (Fig. 6a, arrowheads), suggesting that these cells are vascular endothelial cells. The other subtype resides interstitially between myofibres and does not have its own laminin staining (Fig. 6b,c, arrows).
Co-staining of muscle tissue sections with CD31, laminin and Pax7 indicated the presence of $C D 31^{\text {pos }} \mathrm{Pax} 7^{\text {neg }}$ cells (Fig. 6d, arrowhead), as well as rare $\mathrm{CD} 31^{\text {pos }} \mathrm{Pax} 7^{\text {pos }}$ cells in the interstitium (Fig. 6e, white arrow), in addition to $\mathrm{CD} 31^{\text {neg }}{ }_{\mathrm{Pax}} 7^{\text {pos }}$ satellite cells (Fig. 6d, yellow arrow).

To trace the developmental origin of MECs in epaxial and hypaxial muscles, Myf5- and MyoD-iCre driver mice were crossed with reporter mice expressing yellow fluorescent protein (YFP) following Cre-mediated excision in the ROSA26 gene locus $\left(R 26 R^{Y F P}\right)$. As expected, satellite cells from trapezius, paraspinal and limb muscles contained between $75-92 \%$ of Myf5 and MyoD-YFP expressing cells (Supplementary Fig. 7A). Following cytospin, expression of Pax7 was detected in $>98 \%$ of the freshly isolated SCs (Supplementary Fig. 7B). In contrast, MECs from all muscles analysed were nearly negative for MyoD expression (Fig. 7a, upper panels), whereas a detectable percentage of Myf5YFP-expressing cells were seen in the MEC fraction of each muscle, particularly in the trapezius and paraspinal muscles, which contain $43 \pm 8 \%$ and $16 \pm 5 \%$ YFPpos MECs, respectively (Fig. 7a, lower panels). Expression of Pax7 following cytospin of Myf5-positive MECs from the trapezius revealed that only $\sim 7 \%$ of the cells expressed Pax7 on isolation (Fig. 7b,c), indicating that, while a substantial proportion of MECs from the trapezius are Myf5-expressing progenitors, they do not express additional myogenic markers. This is also in agreement with the finding that the majority of $\mathrm{CD} 31^{\text {pos }}$ cells are Pax $7^{\text {neg }}$ by immunohistochemistry. To explore whether MECs could adopt a myogenic fate following expansion in vitro, they were propagated in myogenic medium for 13 days and expression of myogenic markers was analysed. At day 3, 97\% of MECs were still positive for both Sca-1 and CD31 (Fig. 7d), while at day 10 and day 13 expression of CD31 was not detected (Fig. 7d,e). At day 10, >90\% MECs were Myf5-YFppos (Fig. 7f), which was also accompanied by uniform expression of Pax7 and MyoD (Fig. 7g).

The in vivo myogenic potential of cultured MECs was assessed by injecting $5 \times 10^{4}$ MECs isolated from $\beta$-actin-EGFP transgenic mice into the TA muscles of C57BL6 recipient mice (Fig. 8a). In parallel, satellite cells were isolated and injected as a positive control for successful engraftment. One month following intramuscular injection of SCs or MECs into TA muscles, transplanted mice displayed obvious presence of GFP-expressing myofibres, demonstrating in vivo myogenic differentiation capacity for MECs (Fig. 8b,c). Thus, while the majority of MECs do not express Pax7 or MyoD on isolation, they acquire expression of myogenic markers following culture in vitro and fuse to myofibres in vivo.

VE-cadherin ${ }^{\text {pos }}$ cells do not significantly contribute to muscle. To address whether MECs can contribute to developing or regenerating muscle in vivo, tracing using a marker expressed by MECs but absent in SCs or APs was performed. Since CD31 ${ }^{\text {Cre }}$ mice are not available, we utilized VE-cadherin, a marker expressed in nearly all MECs by antibody analysis, whereas APs and SCs were negative (Fig. 9a). Tracing of MECs in developing muscle was tested using a VE-cadherin Cre $\left(\mathrm{Cdh} 5^{\mathrm{Cre}}\right)$ driver $^{43}$ crossed with a $R 26 R^{Y F P}$ reporter mouse. Analysis of $C d h 5^{C r e}: R 26 R^{Y F P}$ mice showed that approximately half of the MECs (43-57\%) were YFP positive under these conditions and therefore traceable (Fig. 9b). The VE-cadherin Cre driver mice were also crossed with R26 ${ }^{\mathrm{NZG}}$ reporters, which resulted in Credependent nuclear LacZ gene expression ${ }^{44}$. Analysis of tissue sections from the trapezius showed that the vast majority of nuclear LacZ-expressing cells did not incorporate into myofibres and were located interstitially between myofibres (Fig. 9c-g, black arrows), consistent with findings reported by other laboratories 
a

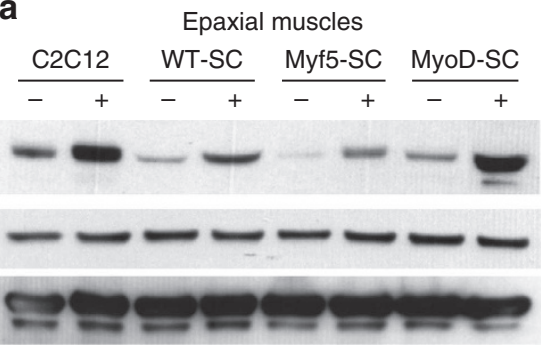

c

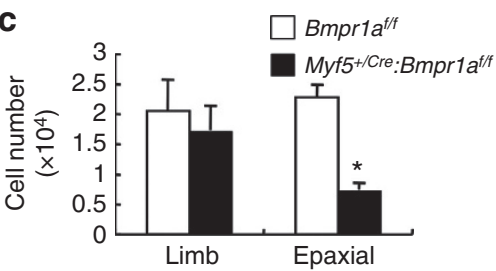

e

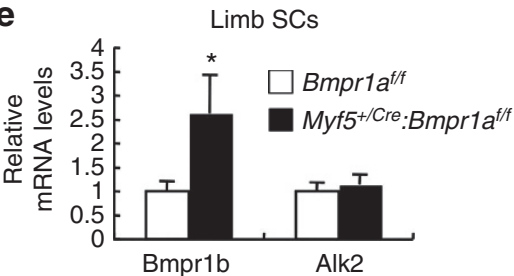

g

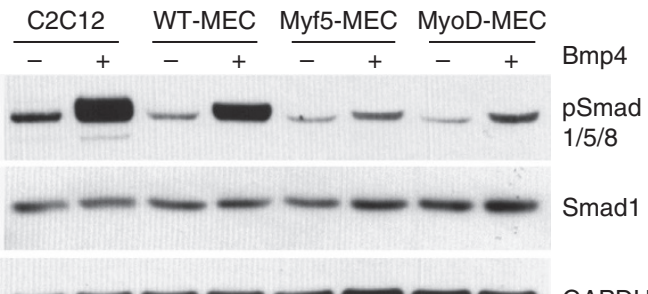

b

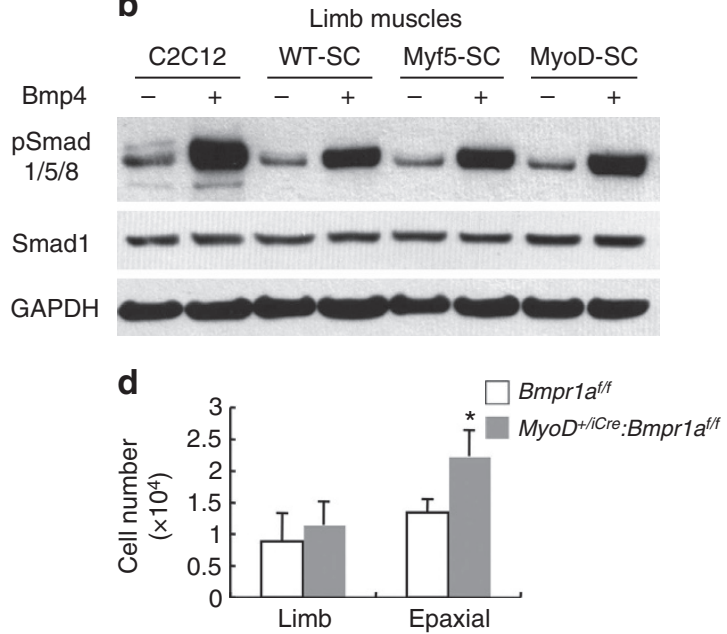

$\mathbf{f}$

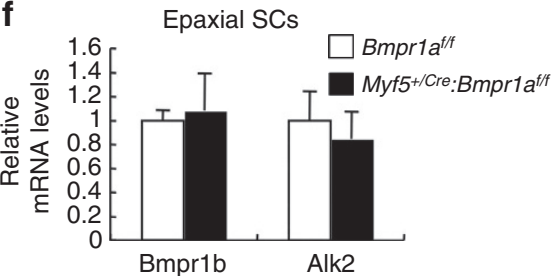

h $\square$ Bmpr1a $^{\text {t/f }}$
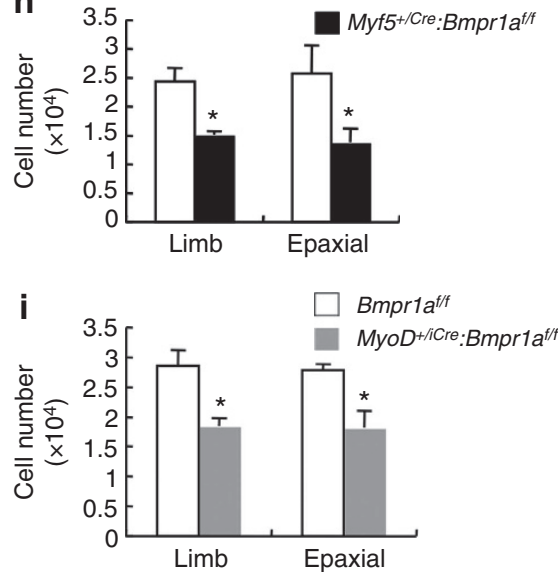

Figure 5 | Ablation of Bmpr1a results in decreased pSmad signalling in MECs. (a,b) Satellite cells from epaxial (paraspinal and trapezius) and limb muscles were isolated from Bmpria $a^{f / f}$ (WT-SC) or Myf5 ${ }^{+/ C r e}:$ Bmpria $a^{f / f}$ (Myf5-SC) or MyoD ${ }^{+/ i C r e}:$ Bmpriat/f (MyoD-SC) mice. Cells were treated with or without $25 \mathrm{ng} \mathrm{ml}^{-1} \mathrm{Bmp} 4$ for $1 \mathrm{~h}$, and cell lysates were analysed for activated pSmad1/5/8 expression by western blotting. $\mathrm{C} 2 \mathrm{C} 12$ cells were treated in parallel as a positive control. Total Smad1 expression levels were similar in all samples analysed. GAPDH expression was used as a loading control. (a) Epaxial Myf5-SCs showed lower levels of activated pSmad1/5/8 under basal conditions or following stimulation with Bmp4 compared to WT-SCs. (b) In contrast, limb satellite cells from both mutant strains appeared unaffected. (c,d) Freshly isolated SCs derived from limb and epaxial muscles of

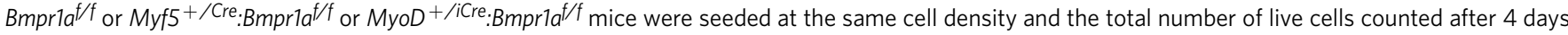
in growth medium. No significant cell death was observed in any culture as examined by Trypan blue staining. (c) Epaxial satellite cells from Myf5 $+/$ Cre. Bmpria $^{f / f}$ mutant mice displayed decreased proliferative potential compared with control $\left({ }^{\star} P<0.05\right)$, while limb satellite cells were unaffected. (d) In

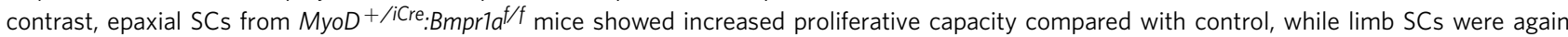
unaffected. (e,f) Relative mRNA expression of Bmpr1b and ALK2 in limb e and epaxial SCs f. Bmpr1b expression was increased in mutant limb SCs, results

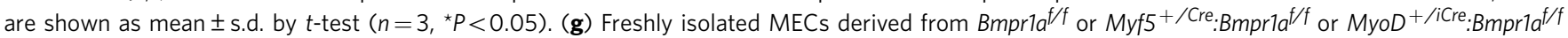
muscles (limb and epaxial) were expanded for 4 days in growth medium and analysed in parallel for pSmad1/5/8 activation. pSmad1/5/8 activity was severely reduced in MECs from both mutant strains, both under basal conditions as well as following Bmp4 stimulation. (h,i) MECs from mutant mice displayed a reduced proliferative capacity compared with control (error bars: s.d., $n=3,{ }^{\star} P<0.05$ by $t$-test), regardless of whether they were isolated from epaxial or limb muscles.

on limb muscles ${ }^{17,23}$. $\beta$-Galactosidase ( $\beta$-gal)-positive nuclei within myofibres were also noted (Fig. 9c-g, red arrows), but these were at very low levels ( $<1 \%$ of myonuclei). Co-staining of $\mathrm{X}$-gal and laminin confirmed the presence of $\beta$-gal-positive myonuclei underneath the basal lamina (Fig. 9h, red arrows) Cardiotoxin injury was also performed in these mice and regenerating muscles were harvested 23 days following injury and stained for $\beta$-gal. Again, the majority of $\beta$-gal-expressing cells 

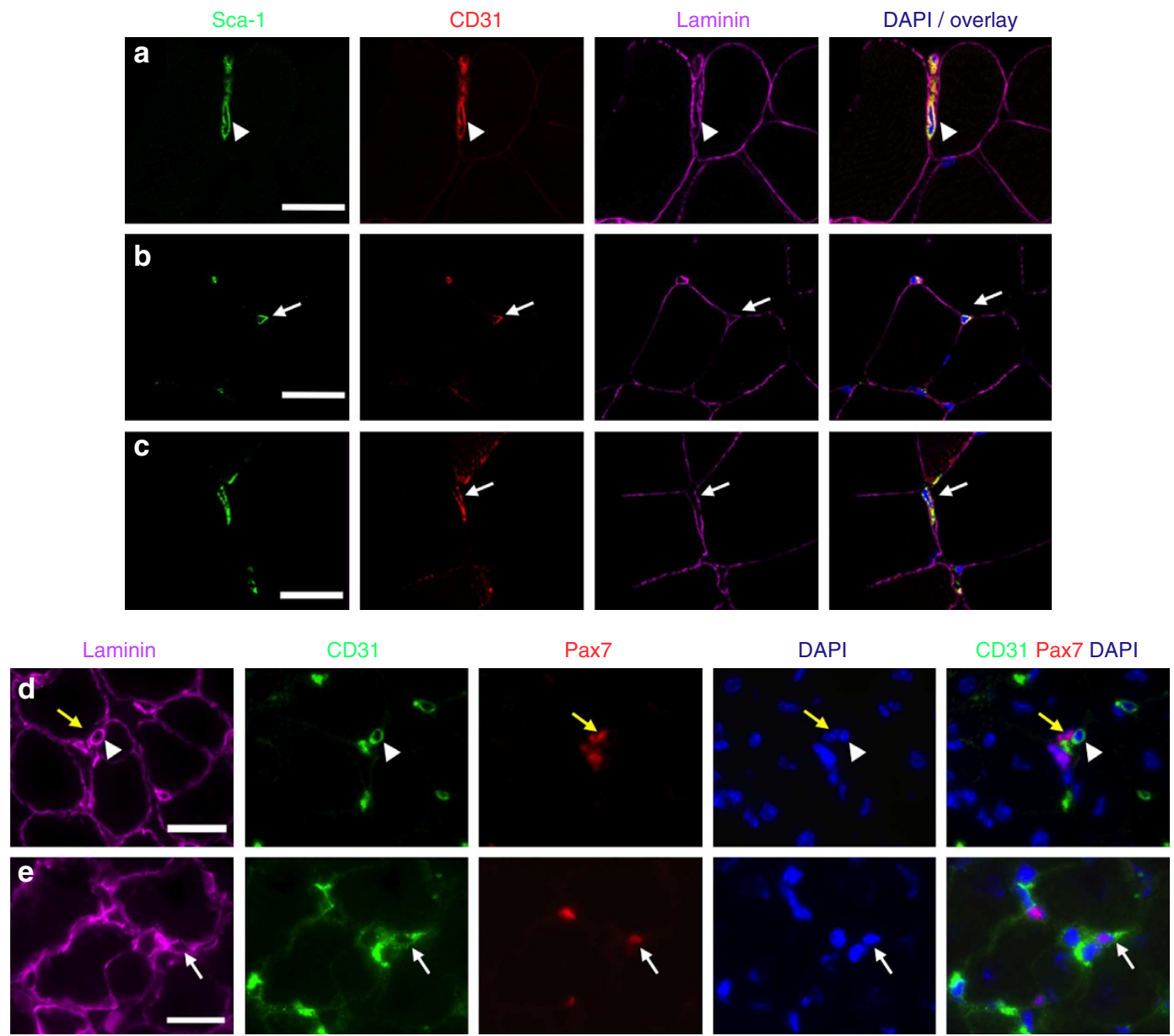

Figure 6 | Detection of endothelial/myo-endothelial cells (MECs) in adult mouse muscle. (a-c) Colocalization of Sca-1 (green), CD31 (red) and laminin (purple) shows co-expression of Sca-1 and CD31 in cells that reside between myofibres with (arrowheads) or without (arrows) their own basal lamina. Scale bar, $20 \mu \mathrm{m}$. (d,e) Immunostaining for laminin (purple) CD31 (green) Pax7 (red), and nuclei (DAPI) detects satellite cells, which reside beneath the basal lamina and are CD31 $1^{\text {neg }}$ Pax $7^{\text {pos }}\left(D\right.$, yellow arrow) as well as CD31 pos Pax $7^{\text {neg }}$ cells (d, white arrowheads), which constitute the vast majority of $\mathrm{CD} 31^{\text {pos }}$ cells, as well as rare $\mathrm{CD} 31^{\text {pos }}$ Pax $7^{\text {pos }}$ cells that reside within the interstitial space and are surrounded by laminin on both sides of the cell (e, white arrow). Scale bar, $20 \mu \mathrm{m}$.

were located in the interstitium (Fig. 9i-k, black arrows), although $\beta$-gal-expressing centrally located nuclei were again noted at very low levels (Fig. 9i-k, red arrows). Thus, Cdh5expressing cells do not contribute to developing or regenerating muscle at biologically significant levels.

\section{Discussion}

Satellite cells are the tissue-specific stem cells of skeletal muscle ${ }^{45-47}$. Additional progenitors located interstitially between myofibres are also present and these consist of various subgroups of cells $12,39,40,48$ whose developmental origin and function have not been fully elucidated. Even less defined are the signalling mechanisms that might influence the fate of these progenitors towards a specific cell lineage. Bone morphogenetic protein signalling regulates the development and differentiation of a variety of tissues ${ }^{49-53}$. In developing skeletal muscle, Bmp signalling inhibits myogenic differentiation and controls the number of fetal muscle progenitors and satellite cells ${ }^{54-56}$. Postnatally, inhibition of Bmp signalling induced by short-term RNAi induced premature differentiation of satellite cells ${ }^{57}$. TGF $\beta$ and Bmp signalling also control the overall muscle mass through myofibres growth, which is mediated via multiple downstream signalling pathways ${ }^{33,34}$. Our previous studies in human fetal muscle identified Bmp4 and Bmprla as a ligand-receptor signalling mechanism between mononuclear cells, through which expansion of interstitial progenitors occurred ${ }^{24}$. Secretion of Bmp4 from side population cells triggered the expansion of interstitial cells co-expressing Myf5 and Bmprla ${ }^{24}$. However, neither whether these Myf5 ${ }^{\text {pos }}$ Bmprla ${ }^{\text {pos }}$ cells are developmentally bona fide myogenic progenitors, nor the exact function of Bmp signalling in these progenitors could be addressed using human samples. In the present study, we generated conditional mouse models that ablated Bmprla expression specifically in Myf5- or MyoD-expressing progenitors to investigate how loss of Bmprla signalling impacts either satellite cells, or intramuscular interstitial progenitors, or both of these cell groups. Overall, Myf5 $5^{+/ C r e}: B m p r 1 a^{\text {t/f }}$ mice displayed a more severe phenotype than $M y o D^{+/ i C r e}:$ Bmprlafff mice, suggesting that Myf5-expressing cells distinct from MyoD pos satellite cells are implicated. Indeed, the progenitors implicated (MECs) are Sca-1 $1^{\text {pos }} \mathrm{CD} 31^{\text {pos }} \mathrm{CD} 45^{\text {neg }}$ and PDGFR $\alpha^{\text {neg }}$ by cell surface markers and are also $\mathrm{MyoD}^{\text {neg }}$. MECs can adopt a myogenic specification following culture in vitro and intramuscular transplantation in vivo, although the contribution of MECs to developing and regenerating muscles is very limited based on VE-cadherin tracing. Thus, the primary function of these cells in vivo is likely not to contribute to 
a
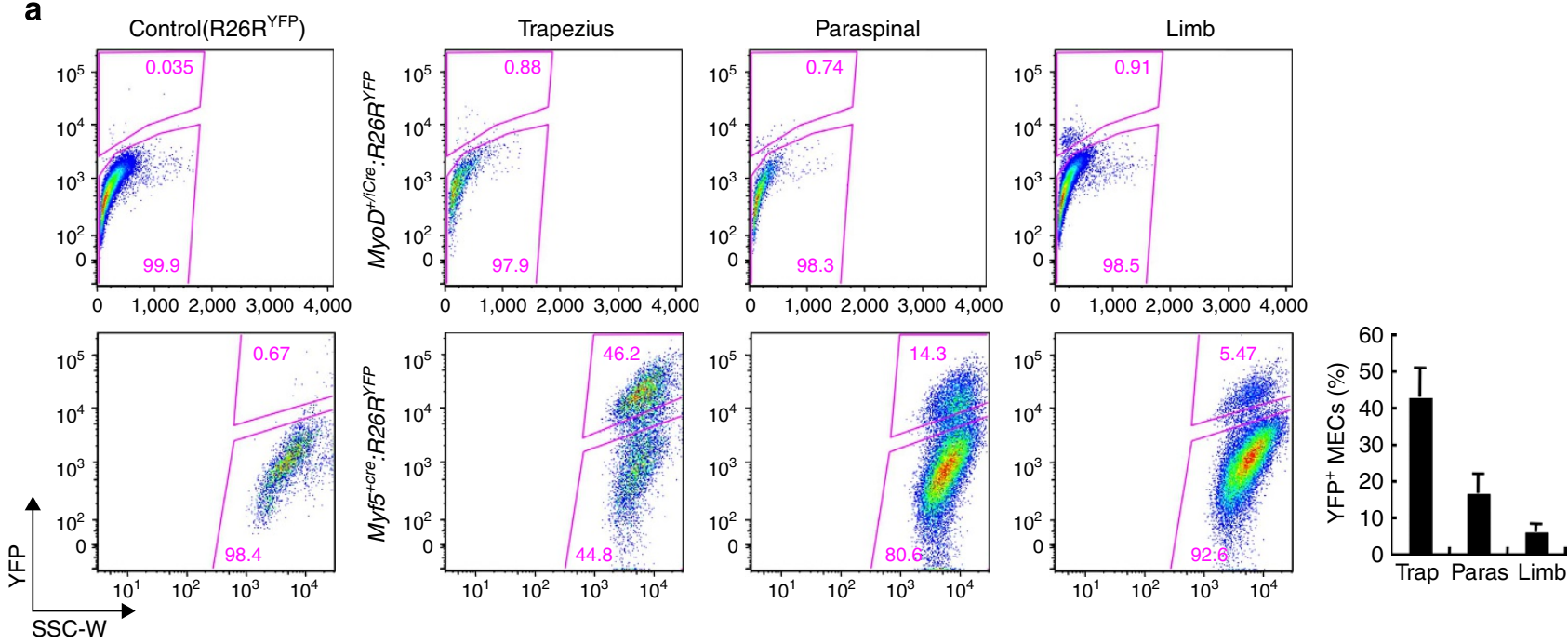

b

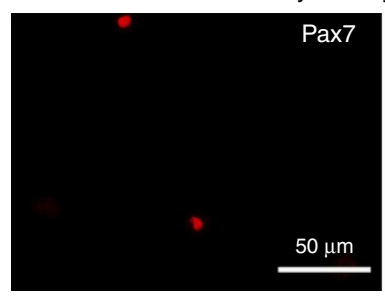

Day 0 Myf5 $5^{\text {pos }}$ MECs

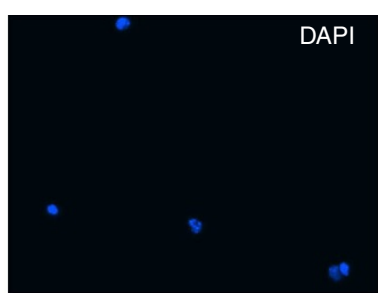

C

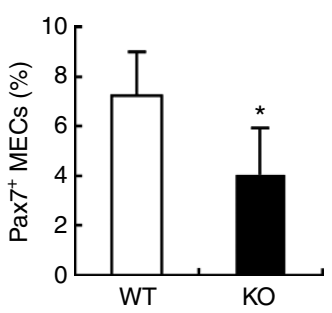

d

Day 3 MECs

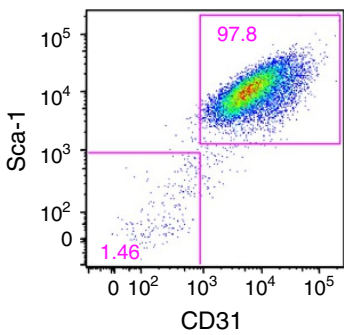

Day 10 Total MECs
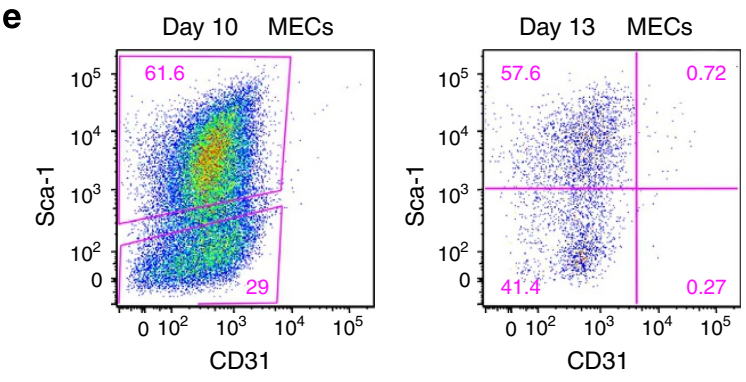

f
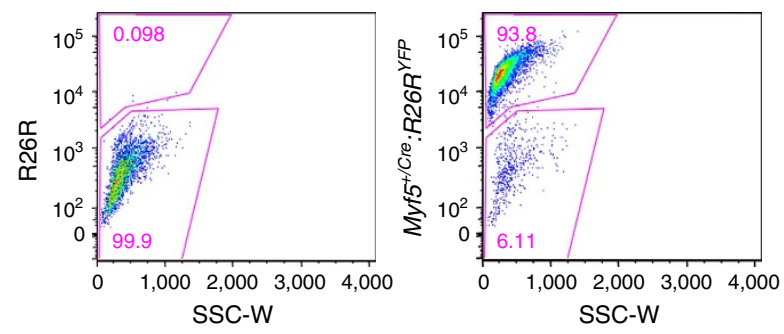

g
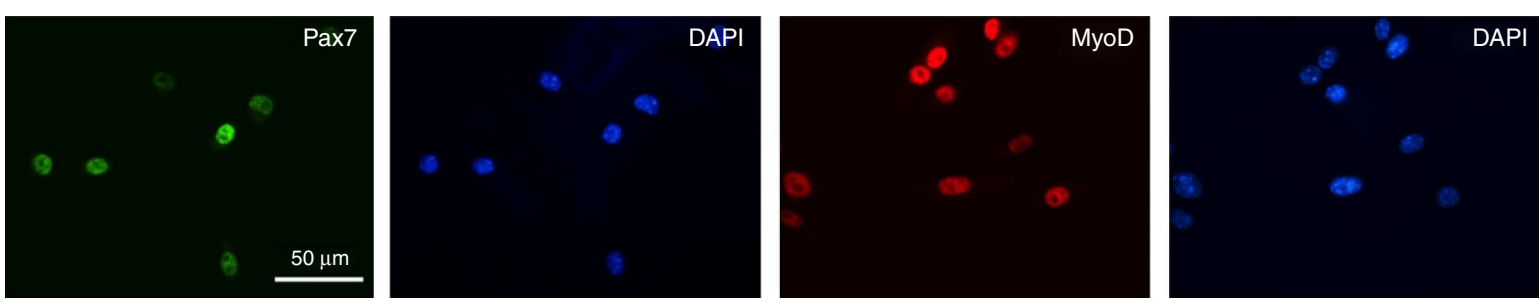

Figure 7 | Expression of myogenic markers in MECs following short-term in vitro culture. (a) FACS sorting plots illustrating expression of YFP in freshly isolated MECs from epaxial or hypaxial muscles of MyoDi+/Cre:R26R ${ }^{Y F P}$ (top row) or Myf5 ${ }^{+/ C r e}: R 26 R^{Y F P}$ reporter mice (bottom row). MyoD-YFP expression was largely negative, while Myf5-YFP expression was detected at variable percentages in all muscles, with the trapezius muscle containing the highest percentage. R26R plots are used as negative control, demonstrating no 'leaky' YFP expression in the studied cell populations. SSC, side scatter. Representative images are from three independent analyses. (b) Cytospins of freshly isolated Myf5 ${ }^{\text {pos }}$ MECs from Myf5 ${ }^{+/ C r e}: R 26 R^{Y F P}$ mice stained for Pax7. Pax7 expression was detected in only 7\% MECs. (c) Pax7 staining of freshly isolated MECs from Bmpr1af/f (WT) and Myf5 $+/$ Cre: Bmpr1af/f (KO) mice revealed that KO-MECs had fewer Pax7-expressing cells than WT-MECs $\left(n=3 ;{ }^{\star} P<0.05\right.$ by $t$-test, error bars $=\mathrm{s}$.d.). (d,e) The majority of MECs remained Sca- $1^{\text {pos }} C D 31^{\text {pos }}$ after 3 days in culture. After 10 days, almost all MECs lost CD31 expression and a fraction became Sca- $1^{\text {neg }} C D 31^{\text {neg }}$, (f) After 10-day culture in myogenic medium, MECs from Myf5 $/ /$ Cre: $R 26 R^{Y F P}$ mice were re-analysed for expression of Myf5-YFP, which was detected in $>90 \%$ of the cells, while no YFP expression was seen in control R26R cultures. (g) Expression of Pax7 and MyoD was detected in $90 \pm 2 \%$ of MECs from Bmpr1a $a^{f / f}$ mice after 10 days in culture, confirming they were myogenic $(n=3)$.

muscle formation, but to support satellite cell activity in inhibiting the differentiation of intramuscular adipogenic progenitors.
MECs require expression of Bmprla to reveal their myogenic potential. Indeed, wild-type MECs differentiated into myotubes both in bulk cultures as well as when grown as clones even under 
a

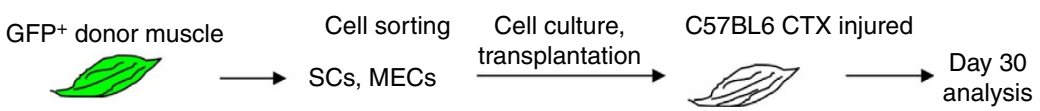

b
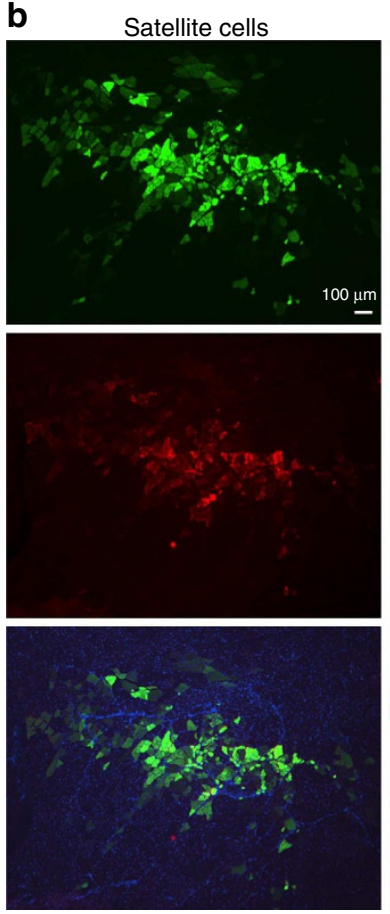

MECs
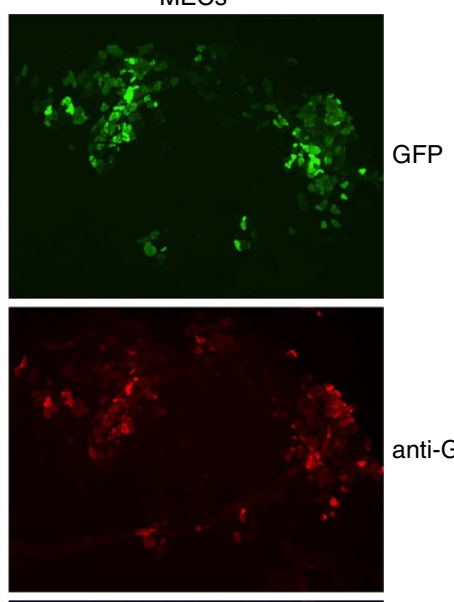

C

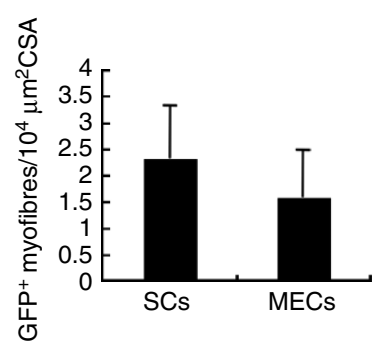

anti-GFP

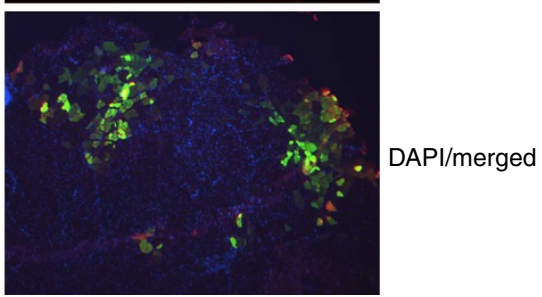

Figure 8 | MECs can engraft and fuse into myofibres following intramuscular transplantation. (a) Schematic representation of intramuscular transplantation of SCs and MECs. (b) Detection of GFP-positive myofibres from C57BL6 TA muscles transplanted with GFPpos SCs or MECs ( $n=4 /$ group). The specificity of GFP-positive myofibres was confirmed by immunostaining with an anti-GFP antibody. (c) MECs showed robust and comparable engraftment as SCs in vivo $(n=4$; error bars $=$ s.d.).

conditions that favour adipogenic differentiation. In contrast, ablation of Bmprla in MECs resulted in severely reduced myogenic activity and increased differentiation into adipocytes. More recently, satellite cells have been shown to adopt a brown adipocyte fate when microRNA-133 expression is downregulated $^{58}$. This appears to be an independent mechanism of cell fate-conversion, as in the current study satellite cells lacking Bmprla remained myogenic even when cultured in adipogenic differentiation medium for 12 days. The development of limb satellite cells in a Bmprla-flawed environment did not seem to affect their activity, possibly because of the activation of compensatory mechanisms, such as the increased expression of the alternative receptor Bmprlb. However, normal limb satellite cell activity was not sufficient to prevent abnormal intramuscular adipogenesis, pointing to a function of MECs in regulating the proliferation and/or differentiation of adipocytes. Altogether, these findings indicate that Bmprla signalling in MECs may block MECs themselves from adopting an adipogenic fate, as well as inhibiting the activity of endogenous intramuscular adipocyte progenitors, as demonstrated by our clonal and in vitro co-culture studies.

In addition to fat infiltration, mutant $M y f 5^{+/ C r e}: B m p r 1 a^{f / f}$ mice exhibited smaller epaxial muscles than wild-type littermates. This phenotype is likely due to impaired function of both satellite cells and interstitial MECs, as reduced SC proliferation and pSmad signalling was also seen in affected epaxial muscles. Collectively, these studies suggest that both SCs and MECs function contribute to the proper formation of epaxial muscles and that Bmprla signalling is critical for the proliferation of both cells types. While ablation of Bmprla in epaxial muscles using a
Myf5 driver influenced the overall size and number of myofibres, limb satellite cells where Bmprla expression was ablated using a MyoD-iCre driver did not seem affected, nor were the size or number of myofibres of the limb muscles analyzed. These results support the conclusion that intramuscular Myf5-expressing cells that are not satellite cells are most affected by altered Bmprla signalling. In support of these findings, recent studies in the extraocular muscle (EOM) highlighted the existence of ancestral Myf5-expressing progenitors that do not express MyoD and exhibit fibro-adipogenic potential. These cells might be derived from the neural crest, as they might be related to cells of Pax-3 origin $^{59}$. While ancestral expression of Pax3 was not assessed in MECs, nor Bmprla expression was tested in this EOM cell fraction, future studies should address similarities between these cell fractions and a possible common developmental origin.

Even though several cell surface and intracellular markers were used to define MECs in the present study, most of these markers are expressed in more than one cell type in skeletal muscle, particularly in cells that are not sublaminar (non-satellite cells) and reside between myofibres or near the vasculature. Therefore, the identification of additional markers unique to some of these interstitial cell fractions, which will distinguish them from one another, is one of the present challenges that need to be overcome to provide better tools to study these different subclasses of interstitial cells.

Tissue localization of MECs in uninjured and regenerating muscle revealed the presence of rare intermyofibre mononuclear cells that were surrounded by laminin staining in both the cytoplasmic and extracellular sides and expressed Pax7. These rare intermyofibre Pax7-expressing cells might be a derivative of 
a
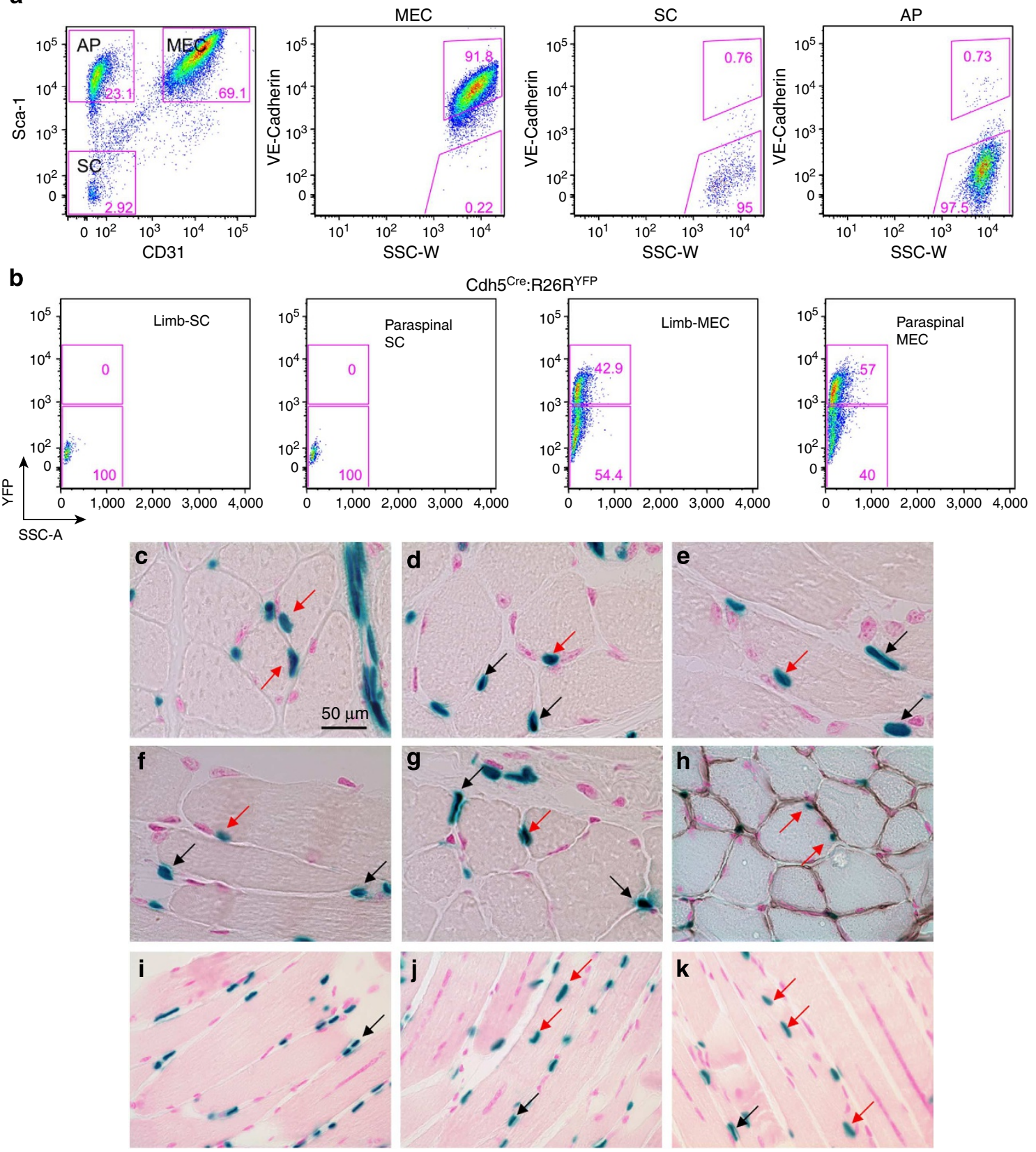

Figure 9 | Modest contribution of MECs to developing muscle via Cdh5 ${ }^{\text {Cre }}$ lineage tracing. (a) FACS analysis of VE-cadherin expression on MECs, SCs and APs via antibody staining. MECs were nearly all positive for VE-Cadherin, while the vast majority of SCs and APs were negative. (b) Detection of VE-cadherin-YFP expression in SCs and MECs using Cdh5 ${ }^{\mathrm{Cre}}: \mathrm{R} 26 \mathrm{R}^{\mathrm{YFP}}$ mice. Again, SCs were all negative for VE-cadherin expression, while only $\sim 40-50 \%$ of MECs were viewed as YFP positive, demonstrating an overall lower labelling yield of MECs when compared with the antibody staining. $(\mathbf{c}-\mathbf{g})$ Detection of $\beta$-gal-positive nuclei (blue) in tissue sections of trapezius muscles of Cdh5 ${ }^{\mathrm{Cre}}: \mathrm{R} 26^{\mathrm{NZG}}$ mice. While most $\beta$-gal-positive nuclei were located between myofibres (black arrows), a very small proportion was also seen incorporated into myofibres (red arrows), as also documented by laminin co-staining (h, brown). (i-k) The same results were obtained for CTX-injured TA muscle.

satellite cells that have separated from myofibres, as previously described for ageing muscle or following denervation ${ }^{60,61}$, or, alternatively, it might be a distinct cell type. In Pax7-ZsGreen reporter mice, 3-16\% of Pax7-expressing cells are also positive for Sca-1 (ref. 62), a marker used in conjunction with CD31 to exclude interstitial cells in routine methods that purify satellite cells ${ }^{19,63,64}$. Thus, these Sca-1 ${ }^{+}$Pax7-ZsGreen cells might include the interstitial Pax7-positive cells localized in the present study. The majority of MECs are not Pax7-positive in vivo, but they gain Pax7, Myf5 and MyoD expression when cultured in vitro. This feature is similar to interstitial cells expressing PW1 that have been described in skeletal muscle as a potential stem cell fraction that participates in myogenesis ${ }^{16}$. Both $\mathrm{PW} 1^{+}$cells and MECs express Sca-1, but PW1 cells do not express CD31 by immunohistochemistry ${ }^{16}$ and MECs exhibit very low expression of PW1 by real-time RT/PCR, suggesting low or minimal overlap between PW1 ${ }^{+}$cells and MECs. Expression of NG2 was also nearly undetectable in MECs, supporting low or minimal overlap between MECs and pericytes ${ }^{17}$. Sca-1 expression has been generally associated with non-satellite cell fractions in skeletal 
muscle ${ }^{19,63,64}$, although it has been complicated by the transient nature of Sca-1 expression associated with the muscle microenvironment, which influences the proliferation and differentiation of myogenic progenitors ${ }^{65,66}$. Thus, additional prospective markers that unequivocally distinguish satellite cells from other interstitial progenitors with myogenic potential will provide potentially better tools to distinguish these cell types, although it cannot be excluded that these distinctions might be blurred or made difficult by intrinsic heterogeneity within the cell fractions or by the possibility that a common progenitor might give rise to both.

In summary, the present study demonstrates that genetic disruption of Bmprla signalling in skeletal muscle suppresses MECs proliferation and yields to increased intramuscular fat. The abnormal fat accumulation observed in mutant muscle might be due to a dual effect: an increased adipogenic differentiation potential of MECs, which could be bipotent progenitors (muscle and fat) and a decreased inhibitory role of SCs and MECs on adipogenic progenitors. Thus, interstitial myo-endothelial progenitors might modulate the balance between muscle and fat, and this function is dependent on Bmp signalling. Ectopic fat cell accumulation is often seen in diseased or ageing muscle. The current findings may highlight a pathway through which inhibition of adipogenic formation could be targeted in these conditions.

\footnotetext{
Methods

Animals. $M y f 5^{+/ C r e}$ (ref. 26) and $M y o D^{+/ i C r e}$ mice ${ }^{29}$ were kindly provided by Dr Amy Wagers (Joslin Diabetes Center, MA) and Dr David Goldhamer (University of Connecticut, CT), respectively. Cdh5 ${ }^{\mathrm{Cre}}$ (VE-cadherin ${ }^{\mathrm{Cre}}$ stock 006137), Rosa26 ${ }^{\mathrm{YFP}}, \mathrm{R} 26^{\mathrm{NZG}}$ and C57BL/6-Tg(ACTBEGFP) $1 \mathrm{Osb} / \mathrm{J}$ ( $\beta$-actinEGFP) mice were obtained from the Jackson Laboratory. Bmprlaf/f mice ${ }^{25}$ were crossed with $M y f 5^{+/ C r e}$ or $M y o D^{+/ i C r e}$ mice to generate mice with muscle lineagespecific deletion of Bmprla (Myf5 $5^{+/ C r e}:$ Bmprlafff or $\left.M y o D^{+/ i C r e}: B m p r l a f / f\right)$. Muscles from both male and female mice of age 4 to 10 weeks were used for FACS analysis. Animals were housed and handled in accordance with the guidelines of the Boston Children's Hospital subcommittee for animal research. All experimental procedures were performed as described in a protocol approved by the IACUC at Boston Children's Hospital.
}

Cardiotoxin injury. Muscle injury was induced by injection of cardiotoxin (15 $\mu \mathrm{l}$ of $0.5 \mu \mathrm{g} \mathrm{ll}^{-1}$ stock) from Naja mossambica (Sigma-Aldrich, MO) into the TA or GA muscle of adult Bmprla f/f, Myf5 $5^{+/ C r e}: B m p r 1 a^{f / f}$ or $M y o D^{+/ i C r e}: B m p r 1 a^{f / f}$ mice. Muscles were harvested at various time points after injection for histological, RNA and protein analyses. Contralateral, uninjected TA or GA muscles were used as controls.

Histology and Immunofluorescence. Mice were killed by $\mathrm{CO}_{2}$ inhalation. For cross-sections of the paraspinal area, the skin was peeled off, and the chest and abdomen were cut open. The whole body was immersed in Bouin's fixative solution, and the samples were processed by the Rodent Histopathology Core Facility at Harvard Medical School. Cross-sections of the paraspinal area were obtained for the determination of myofibre size and the number of myofibres. For trapezius, non-injured or CTX-injured TA and GA muscles were dissected, embedded for cryostat sectioning and rapidly frozen in cold isopentane ${ }^{67}$. Muscle tissue sections $(10 \mu \mathrm{m})$ were subjected to $\mathrm{H} \& \mathrm{E}$ staining and the myofibre size was determined by measuring the cross-sectional area (CSA). Regeneration was analysed by measuring the diameter of regenerating myofibres with centrally localized nuclei. Measurements were performed using Image J software (National Institute of Health; http://rsb.info.nih.gov/ij/).

For immunofluorescence, cells or tissue sections were fixed in $4 \%$ paraformaldehyde for $10 \mathrm{~min}$, permeabilized with $0.1 \%$ Triton X-100 in PBS for $10 \mathrm{~min}$ and blocked with $1 \%$ BSA and 5\% donkey serum in PBS for $1 \mathrm{~h}$. Cells or tissue sections were incubated with the primary antibodies overnight at $4{ }^{\circ} \mathrm{C}$ diluted as follows: rabbit anti MyoD (Santa Cruz Biotech, 1:50), mouse anti-desmin (DAKO, 1:100), biotin anti-mouse Sca-1 (Biolegend, 1:100), rat anti- mouse CD31 (BD Pharmingen, 1:100), rabbit anti-laminin (Sigma-Aldrich, 1:500), rabbit antiperilipin (Sigma-Aldrich, 1:150). Slides were washed in $1 \times$ PBS three times, $10 \mathrm{~min}$ each and incubated with the appropriate secondary antibodies for $1 \mathrm{~h}$ at room temperature. Slides were washed again with PBS as above and mounted in Vectashield (Vector Laboratories, CA) supplemented with $100 \mathrm{ng} \mathrm{ml}^{-1}$ DAPI to visualize nuclei. Epifluorescent images were captured using a Nikon Eclipse E-1000 microscope equipped with a Hamamatsu digital camera, and images were acquired using Openlab software version 3.1.5 (Improvision).
Pax7 immunofluorescence on tissue sections. Muscle tissue sections $(10 \mu \mathrm{m})$ were prepared using a cryostat and let dry at room temperature (RT). Sections were fixed in 2\% PFA diluted in PBS for $10 \mathrm{~min}$, then washed $3 \times 5 \mathrm{~min}$ in PBS. Sections were dehydrated with gentle shaking in $50,70,80,95$ and $100 \%$ (twice) ethanol/ water. Slides were incubated in xylene $2 \times 3 \mathrm{~min}$ and rehydrated $(3 \mathrm{~min}$ each, gentle shaking) in 95 and $70 \%$ ethanol, followed by $1 \times$ PBS. To unmask antigens, slides were incubated for $20 \mathrm{~min}$ in $0.01 \mathrm{M} \mathrm{NaCitrate} \mathrm{pH} 6.0$ in a steamer, then rinsed with $1 \times$ PBS. Slides were then permeabilized with $0.5 \%$ triton X -100 in PBS for $10 \mathrm{~min}$, then rinsed with $1 \times$ PBS. Sections were blocked in blocking solution $(2 \%$ horse serum, $2 \%$ goat serum $2 \%$ BSA (fraction V) $0.1 \%$ triton X 100, made in PBS) for $30 \mathrm{~min}$ at RT, followed by blocking with MOM kit blocking solution (Vector labs) for $30 \mathrm{~min}$ at RT. Primary antibodies were diluted in MOM diluent and incubated overnight at $4^{\circ} \mathrm{C}$ as follows: mouse anti-Pax7 (Developmental Studies Hybridoma Bank, concentrated supernatant, diluted 1:100), rabbit anti-laminin (Sigma-Aldrich, 1:500). Sections were rinsed with PBS $(4 \times 5 \mathrm{~min}$ each), then appropriate secondary Abs (Jackson ImmunoResearch) were diluted in MOM diluent $(1: 100)$ and incubated for $1 \mathrm{~h}$ at RT. Slides were then washed for $4 \times 5 \mathrm{~min}$ in PBS and mounted in DAPI/Vectashield mounting medium. Slides were analysed and images acquired as described above.

X-gal Staining. Muscle tissues were excised and frozen in liquid nitrogen-cooled isopentane. Tissue sections $(10 \mu \mathrm{m})$ were fixed in $0.2 \%$ glutaraldehyde, $2 \mathrm{mM}$ $\mathrm{MgCl}_{2}$ for $10 \mathrm{~min}$ at room temperature and then washed briefly two times in PBS and one time with LacZ wash buffer containing $2 \mathrm{mM} \mathrm{MgCl}_{2}, 0.01 \%$ Deoxycholate, $0.02 \% \mathrm{NP}-40$ in PBS. Fixed sections were stained overnight in 5-bromo-4-chloro-3indolyl-'-D-galactopyranoside (X-gal) working solution at $37^{\circ} \mathrm{C}$. The X-gal working solution contained $5 \mathrm{mM}$ potassium hexacyanoferrate (III), $5 \mathrm{mM}$ potassium hexacyanoferrate (II) trihydrate and $1 \mathrm{mg} \mathrm{ml}^{-1}$ of X-gal in Lacz wash buffer Following the overnight incubation, sections were washed three times for $10 \mathrm{~min}$ per wash in PBS, stained with nuclear fast red for $3 \mathrm{~min}$, dehydrated in 70, 95 and $100 \%$ ethanol for $2 \mathrm{~min}$ each, cleared for $1 \mathrm{~min}$ in xylene and then mounted on a coverslip using Permount mounting media. For co-staining of X-gal and laminin, tissue sections were stained with the laminin antibody as described above and HRP-conjugated anti-rabbit secondary antibody, followed by $3,3^{\prime}$-diaminobenzidine (DAB) detection (Vector labs). Afterwards, the specimens were stained for $\mathrm{X}$-gal.

Oil Red $O$ staining. Lipid accumulation was visualized by staining cells or tissue sections with the lipid-specific dye Oil Red O (Sigma-Aldrich, MO). In brief, $8-10 \mu \mathrm{m}$ tissue sections or cells were fixed with $10 \%$ formalin and rinsed with tap water for 1-10 min before being rinsed in $60 \%$ isopropanol. Slides were then placed in $0.25 \%$ Oil Red $\mathrm{O}$ solution in isopropanol for $8-10 \mathrm{~min}$ in a $60^{\circ} \mathrm{C}$ oven. Slides were rinsed again in $60 \%$ isopropanol, and nuclei were stained in alum haematoxylin for $1 \mathrm{~min}$, followed by a rinse in distilled water and mounted in aqueous solution.

Fluorescence-activated cell sorting. Pooled epaxial and hypaxial skeletal muscles were harvested, minced using sterile scalpels and digested at $37^{\circ} \mathrm{C}$ for $45 \mathrm{~min}$ using a final concentration of $1.2 \mathrm{U}$ dispase II (Roche Applied Science, IN) and $5 \mathrm{mg}$ collagenase D (Roche Applied Science, IN) per gram of tissue with gentle trituration every $15 \mathrm{~min}$. Digestion was terminated by addition of growth medium. Digested samples were filtered through a $40-\mu \mathrm{m}$ cell strainer, spun down and treated with RBC lysis buffer (Qiagen, Valencia, CA). Cells were spun down and resuspended in ice-cold $1 \times$ HBSS (Hank's buffered salt solution, Invitrogen) containing $0.5 \% \mathrm{BSA}$ at a concentration of $2 \times 10^{7} \mathrm{cells} \mathrm{ml}^{-1}$. Antibodies were added at the following dilutions: anti-mouse CD45 (1:300, PE-Cy7 conjugate, clone 30-F11), anti-mouse Sca-1 (Ly-6A/E, 1:100, FITC or APC-Cy7 conjugate, clone E13-161.7), anti-mouse CD31 (1:200, APC or PE conjugate, clone MEC13.3) (all from BD Pharmingen, CA), anti-mouse PDGFR1 $\alpha$ (1:100, APC or biotin conjugate, clone APA5, Biolegend, CA), anti-mouse CD106 (VCAM-1, 1:75, FITC or PE conjugate, clone 429, Biolegend, CA, anti-mouse VE-cadherin (1:100, clone 11D4.1, BD Pharmingen, CA). Cells and diluted antibodies were incubated on ice for $20 \mathrm{~min}$, washed with cold $1 \times$ HBSS/ $0.5 \%$ BSA and resuspended at a concentration of $10^{7}$ cells $\mathrm{ml}^{-1}$. To select for live cells by flow cytometry, calcein blue (Invitrogen, CA) was added at a final concentration of $4.65 \mu \mathrm{g} \mathrm{ml}^{-1}$, and propidium iodide (PI, Sigma-Aldrich, MO) was added at a final concentration of $1 \mu \mathrm{g} \mathrm{ml}^{-1}$. Live cells were selected by positive staining for calcein blue and negative staining for PI. Cells were sorted on either a FACSVantage SE or BD FACSAria flow cytometer (both from Becton Dickinson, NJ). FACS data were collected using CellQuest software version 3.3 or DIVA software (Becton Dickinson) and analysed using Flowjo software (Tree Star, Macintosh version 6.4.7)

In vitro primary cell culture. Satellite cells were plated on tissue culture dishes coated with Matrigel (BD Bioscience, MA) and cultured in growth medium (1:1 mixture of DMEM-high glucose and Ham's F-10 medium; $20 \%$ fetal bovine serum, $5 \mathrm{ng} \mathrm{ml}^{-1}$ basic fibroblast growth factor, $100 \mathrm{U} \mathrm{ml}^{-1}$ penicillin, $100 \mu \mathrm{g} \mathrm{ml}^{-1}$ streptomycin and $2 \mathrm{mM}$ L-glutamate). Myoblast differentiation was induced by switching cells from growth to differentiation medium (DMEM with low glucose, $2 \%$ horse serum, $100 \mathrm{U} \mathrm{ml}^{-1}$ penicillin, $100 \mu \mathrm{g} \mathrm{ml}^{-1}$ streptomycin and $2 \mathrm{mM}$ 
L-glutamate). Cells were differentiated for 4 days under these conditions and monitored for myotube formation.

To expand MECs and APs, freshly isolated cells were propagated in MCDB medium containing 60\% DMEM with low glucose (Invitrogen, CA) and $40 \%$ MCDB201 (Sigma-Aldrich, MO), supplemented with $100 \mathrm{U} \mathrm{ml}^{-1}$ penicillin and $100 \mu \mathrm{g} \mathrm{ml}^{-1}$ streptomycin (Invitrogen, CA). The medium was supplemented with $2 \% \mathrm{FBS}, 1 \times$ insulin-transferrin-selenium mix, $1 \times$ linoleic acid conjugated to BSA, $1 \mathrm{nM}$ dexamethasone and $0.1 \mathrm{mM}$ L-ascorbic acid 2-phosphate (all from SigmaAldrich, MO). The following growth factors were also added to the medium: $10 \mathrm{ng} \mathrm{ml}^{-1}$ epidermal growth factor (PeproTech, NJ), $10 \mathrm{ng} \mathrm{ml}^{-1}$ leukemia inhibitory factor (Millipore, MA), $10 \mathrm{ng} \mathrm{ml}^{-1}$ platelet-derived growth factor BB (PeproTech, NJ) and $5 \mathrm{ng} \mathrm{ml}^{-1}$ basic fibroblast growth factor (Sigma-Aldrich, $M O)^{42}$. To assay for proliferation, freshly isolated SCs and MECs were plated at 2,500 cells per well and 5,000 cells per well, respectively, in 24-well plates, and the total number of live cells was counted 4 days after culture in growth medium. Dead cells were stained by Trypan blue but were found not to be different in number between cultures. To induce adipogenic differentiation, cells were treated for $48 \mathrm{~h}$ with MCDB medium containing $5 \mu \mathrm{g} \mathrm{ml}^{-1}$ human insulin (Roche Applied Science, IN), $50 \mu \mathrm{M}$ indomethacin, $1 \mu \mathrm{M}$ dexamethasone, $0.5 \mu \mathrm{M}$ isobutylmethylxanthine (IBMX) and $1 \mathrm{nM} \mathrm{3,} \mathrm{3',} \mathrm{5-triiodo--t-thyronine} \mathrm{(T3)} \mathrm{(all} \mathrm{from} \mathrm{Sigma-Aldrich,} \mathrm{MO),}$ followed by further differentiation for 7 days in MCDB medium with the addition of T3 and insulin only. Adeno ${ }^{\text {Cre }}$ virus (Gene Transfer Vector Core, University of Iowa, Iowa) was applied at a concentration of 50 p.f.u. per cell.

For co-culture, $5 \times 10^{4} \mathrm{AP}$ cells sorted from $\beta$-actin-EGFP transgenic mice and $2.5 \times 10^{4}$ MECs derived from Bmprlaf/f or Myf5 $5^{+/ C r e}:$ Bmprlat/f muscle were co-seeded in each well and cultured in MCDB growth medium for 4 days followed by adipogenic differentiation for 9 days. For conditioned cultures, MECs from Bmprlatff or Myf5 $5^{+/ C r e}: B m p r 1 a^{f / f}$ muscle were expanded in MCDB growth medium for 4 days and were then treated with adipogenic medium for 9 days. The supernatant was collected every other day, filtered through a $0.45-\mu \mathrm{m}$ filter and used as conditioned medium (mixed with fresh medium in a 1:1 ratio) in the cultures containing GFP ${ }^{\mathrm{pos}} \mathrm{AP}$ cells.

Clonal assay. MECs isolated from Bmprla ${ }^{\mathrm{f} / \mathrm{f}}$ muscles were treated with or without Adeno ${ }^{\text {Cre }}$ virus at a concentration of 50 p.f.u. per cell for $48 \mathrm{~h}$. Single cells were then sorted to 96-well plate by FACS and cultured with conditioned medium (MCDB growth medium collected from MEC proliferating culture, filtered and mixed with fresh medium in a 1:1 ratio) until colony formed. Four 96-well plates were generated for control cells and for cells treated with Adeno-Cre. Clones were then induced for adipogenic differentiation as described above.

Western blot analyses. Protein lysates were obtained from freshly isolated or cultured cells. Cells were lysed on ice for $15 \mathrm{~min}$ in $0.2 \mathrm{ml}$ lysis buffer $(50 \mathrm{mM}$ Tris, pH 7.4, $150 \mathrm{mM} \mathrm{NaCl}, 1 \%$ NP-40, 0.1\% SDS and Halt Protease Inhibitor Cocktail (Pierce Biotechnology). Cell lysates were collected and centrifuged at 15,000 g for $10 \mathrm{~min}$ at $4{ }^{\circ} \mathrm{C}$. Protein concentration was determined using the BioRad Bradford assay. Protein lysates were analysed on Invitrogen NuPage Novex Bis-Tris 4-12\% gradient gels with MES-SDS buffer. Gels were transferred onto nitrocellulose using the Invitrogen NuPage Transfer system. Western blots were performed using antibodies recognizing pSmad 1/5/8, pSmad2, Smad1 (Cell Signaling Technology, MA), Pax7 (Developmental Studies Hybridoma Bank, concentrated supernatant) and glyceraldehyde 3-phosphate dehydrogenase (GAPDH) (Santa Cruz Biotechnology, CA), all diluted 1:1,000.

RNA isolation and Quantitative RT-PCR analysis. Total RNA was isolated from tissues or cultured cells using Tri-reagent (Molecular Research Center, OH). Reverse transcription was performed using the Invitrogen Superscript III First Strand Synthesis kit for RT-PCR according to the manufacturer's instructions (Invitrogen, CA), starting with $1 \mu \mathrm{g}$ of total RNA. Primers were added at a final concentration of $80 \mathrm{nM}$, and the sequences are listed in Supplementary Table 1. Quantitative real-time PCR was performed with the SYBR Green PCR master mix kit (Applied Biosystems, CA) using an ABI7900HT PCR machine under 'default' conditions: $50^{\circ} \mathrm{C}$ for $2 \mathrm{~min}$ and $95^{\circ} \mathrm{C}$ for $10 \mathrm{~min}$, followed by 40 cycles of amplification at $94^{\circ} \mathrm{C}$ for $15 \mathrm{~s}$ and $60^{\circ} \mathrm{C}$ for $1 \mathrm{~min}$. Melting curves for each primer pair were assessed to ensure specific amplification. The transcript levels were normalized to those of GAPDH.

In vivo transplantation of MECs and SCs. MECs and SCs sorted from $\beta$-actinEGFP transgenic skeletal muscle were expanded for 5 days in culture and then 50,000 cells were transplanted into the TA muscle of C57BL6 mice. The TA muscle was subjected to cardiotoxin injury 1 day before cell transplantation. After 30 days, the recipient muscle was analysed for GFP-positive myofibres as previously described ${ }^{68}$.

Statistical analysis. All values are presented as the mean \pm s.d. from at least three independent experiments unless otherwise stated. Two-tailed Student's $t$-test and one-way ANOVA were employed for statistical analyses with two groups and more than two groups, respectively. $P$-values less than 0.05 were considered to represent statistically significant differences.

\section{References}

1. Bentzinger, C. F., von Maltzahn, J. \& Rudnicki, M. A. Extrinsic regulation of satellite cell specification. Stem Cell Res. Ther. 1, 27 (2010).

2. Scharner, J. \& Zammit, P. S. The muscle satellite cell at 50: the formative years. Skelet. Muscle 1, 28 (2011).

3. Yablonka-Reuveni, $\mathrm{Z}$. The skeletal muscle satellite cell: still young and fascinating at 50. J. Histochem. Cytochem. 59, 1041-1059 (2011).

4. Dhawan, J. \& Rando, T. A. Stem cells in postnatal myogenesis: molecular mechanisms of satellite cell quiescence, activation and replenishment. Trends. Cell. Biol. 15, 666-673 (2005).

5. Kassar-Duchossoy, L. et al. Pax3/Pax7 mark a novel population of primitive myogenic cells during development. Genes Dev. 19, 1426-1431 (2005).

6. Zammit, P. S. et al. Pax7 and myogenic progression in skeletal muscle satellite cells. J. Cell. Sci. 119, 1824-1832 (2006).

7. Kuang, S., Kuroda, K., Le Grand, F. \& Rudnicki, M. A. Asymmetric self-renewal and commitment of satellite stem cells in muscle. Cell 129, 999-1010 (2007).

8. Braun, T., Rudnicki, M. A., Arnold, H. H. \& Jaenisch, R. Targeted inactivation of the muscle regulatory gene Myf-5 results in abnormal rib development and perinatal death. Cell 71, 369-382 (1992).

9. Rudnicki, M. A., Braun, T., Hinuma, S. \& Jaenisch, R. Inactivation of MyoD in mice leads to up-regulation of the myogenic HLH gene Myf-5 and results in apparently normal muscle development. Cell 71, 383-390 (1992).

10. Rudnicki, M. A. \& Jaenisch, R. The MyoD family of transcription factors and skeletal myogenesis. Bioessays 17, $203-209$ (1995).

11. Day, K., Paterson, B. \& Yablonka-Reuveni, Z. A distinct profile of myogenic regulatory factor detection within $\mathrm{Pax} 7+$ cells at $S$ phase supports a unique role of Myf5 during posthatch chicken myogenesis. Dev. Dynamics 238, 1001-1009 (2009).

12. Peault, B. et al. Stem and progenitor cells in skeletal muscle development, maintenance, and therapy. Mol. Ther. 15, 867-877 (2007).

13. Tamaki, T. et al. Identification of myogenic-endothelial progenitor cells in the interstitial spaces of skeletal muscle. J. Cell Biol. 157, 571-577 (2002).

14. Dellavalle, A. et al. Pericytes of human skeletal muscle are myogenic precursors distinct from satellite cells. Nat. Cell Biol. 9, 255-267 (2007).

15. Zheng, B. et al. Prospective identification of myogenic endothelial cells in human skeletal muscle. Nat. Biotechnol. 25, 1025-1034 (2007).

16. Mitchell, K. J. et al. Identification and characterization of a non-satellite cell muscle resident progenitor during postnatal development. Nat. Cell Biol. 12, 257-266 (2010).

17. Dellavalle, A. et al. Pericytes resident in postnatal skeletal muscle differentiate into muscle fibres and generate satellite cells. Nat. Commun. 2, 499 (2011).

18. Doyle, M. J. et al. Abcg2 labels multiple cell types in skeletal muscle and participates in muscle regeneration. J. Cell Biol. 195, 147-163 (2011).

19. Joe, A. W. et al. Muscle injury activates resident fibro/adipogenic progenitors that facilitate myogenesis. Nat. Cell Biol. 12, 153-163 (2010).

20. Natarajan, A., Lemos, D. R. \& Rossi, F. M. Fibro/adipogenic progenitors: a double-edged sword in skeletal muscle regeneration. Cell Cycle 9, 2045-2046 (2010).

21. Uezumi, A., Fukada, S., Yamamoto, N., Takeda, S. \& Tsuchida, K. Mesenchymal progenitors distinct from satellite cells contribute to ectopic fat cell formation in skeletal muscle. Nat. Cell Biol. 12, 143-152 (2010).

22. Sambasivan, R. et al. Pax7-expressing satellite cells are indispensable for adult skeletal muscle regeneration. Development 138, 3647-3656 (2011).

23. Wosczyna, M. N., Biswas, A. A., Cogswell, C. A. \& Goldhamer, D. J. Multipotent progenitors resident in the skeletal muscle interstitium exhibit robust BMP-dependent osteogenic activity and mediate heterotopic ossification. J. BoneMineral Res. 27, 1004-1017 (2012).

24. Frank, N. Y. et al. Regulation of myogenic progenitor proliferation in human fetal skeletal muscle by BMP4 and its antagonist Gremlin. J. Cell Biol. 175, 99-110 (2006).

25. Mishina, Y., Hanks, M. C., Miura, S., Tallquist, M. D. \& Behringer, R. R. Generation of Bmpr/Alk3 conditional knockout mice. Genesis 32, 69-72 (2002)

26. Tallquist, M. D., Weismann, K. E., Hellstrom, M. \& Soriano, P. Early myotome specification regulates PDGFA expression and axial skeleton development. Development 127, 5059-5070 (2000).

27. Braun, T. \& Arnold, H. H. Myf-5 and myoD genes are activated in distinct mesenchymal stem cells and determine different skeletal muscle cell lineages. EMBO J. 15, 310-318 (1996)

28. Kablar, B. et al. MyoD and Myf-5 differentially regulate the development of limb versus trunk skeletal muscle. Development 124, 4729-4738 (1997).

29. Kanisicak, O., Mendez, J. J., Yamamoto, S., Yamamoto, M. \& Goldhamer, D. J. Progenitors of skeletal muscle satellite cells express the muscle determination gene, MyoD. Dev. Biol. 332, 131-141 (2009).

30. Stuelsatz, P., Keire, P., Almuly, R. \& Yablonka-Reuveni, Z. A contemporary atlas of the mouse diaphragm: myogenicity, vascularity, and the pax3 connection. J. Histochem. Cytochem. 60, 638-657 (2012).

31. Couteaux, R., Mira, J. C. \& d'Albis, A. Regeneration of muscles after cardiotoxin injury. I. Cytological aspects. Biol. Cell 62, 171-182 (1988). 
32. Cooper, R. N. et al. In vivo satellite cell activation via Myf5 and MyoD in regenerating mouse skeletal muscle. J. Cell Sci. 112(Pt 17): 2895-2901 (1999).

33. Sartori, R. et al. BMP signaling controls muscle mass. Nat. Genet. 45, 1309-1318 (2013)

34. Winbanks, C. E. et al. The bone morphogenetic protein axis is a positive regulator of skeletal muscle mass. J. Cell Biol. 203, 345-357 (2013).

35. Sieber, C., Kopf, J., Hiepen, C. \& Knaus, P. Recent advances in BMP receptor signaling. Cytokine. Growth Factor Rev. 20, 343-355 (2009).

36. Fukada, S. et al. Molecular signature of quiescent satellite cells in adult skeletal muscle. Stem Cell 25, 2448-2459 (2007).

37. Lawlor, M. W. et al. Myotubularin-deficient myoblasts display increased apoptosis, delayed proliferation, and poor cell engraftment. Am. J. Pathol. 181, 961-968 (2012).

38. De Angelis, L. et al. Skeletal myogenic progenitors originating from embryonic dorsal aorta coexpress endothelial and myogenic markers and contribute to postnatal muscle growth and regeneration. J. Cell Biol. 147, 869-878 (1999).

39. Pannerec, A., Marazzi, G. \& Sassoon, D. Stem cells in the hood: the skeletal muscle niche. Trends Mol. Med. 18, 599-606 (2012).

40. Pannerec, A., Formicola, L., Besson, V., Marazzi, G. \& Sassoon, D. A. Defining skeletal muscle resident progenitors and their cell fate potentials. Development 140, 2879-2891 (2013).

41. Liadaki, K. et al. beta4 integrin marks interstitial myogenic progenitor cells in adult murine skeletal muscle. J. Histochem. Cytochem. 60, 31-44 (2012).

42. Schulz, T. J. et al. Identification of inducible brown adipocyte progenitors residing in skeletal muscle and white fat. Proc. Natl Acad. Sci. USA 108, 143-148 (2011).

43. Alva, J. A. et al. VE-Cadherin-Cre-recombinase transgenic mouse: a tool for lineage analysis and gene deletion in endothelial cells. Dev. Dynamics 235, 759-767 (2006).

44. Yamamoto, M. et al. A multifunctional reporter mouse line for Cre- and FLP-dependent lineage analysis. Genesis 47, 107-114 (2009).

45. Brack, A. S. \& Rando, T. A. Tissue-specific stem cells: lessons from the skeletal muscle satellite cell. Cell Stem Cell 10, 504-514 (2012).

46. Relaix, F. \& Zammit, P. S. Satellite cells are essential for skeletal muscle regeneration: the cell on the edge returns centre stage. Development 139, 2845-2856 (2012).

47. Yin, H., Price, F. \& Rudnicki, M. A. Satellite cells and the muscle stem cell niche. Physiol. Rev. 93, 23-67 (2013).

48. Judson, R. N., Zhang, R. H. \& Rossi, F. M. Tissue-resident mesenchymal stem/progenitor cells in skeletal muscle: collaborators or saboteurs? FEBS. J. 280, 4100-4108 (2013).

49. Shi, Y. \& Massague, J. Mechanisms of TGF-beta signaling from cell membrane to the nucleus. Cell 113, 685-700 (2003).

50. Hong, C. C. \& Yu, P. B. Applications of small molecule BMP inhibitors in physiology and disease. Cytokine Growth Factor Rev. 20, 409-418 (2009).

51. Rosen, V. BMP2 signaling in bone development and repair. Cytokine Growth Factor Rev. 20, 475-480 (2009).

52. Rider, C. C. \& Mulloy, B. Bone morphogenetic protein and growth differentiation factor cytokine families and their protein antagonists. Biochem. J. 429, 1-12 (2010).

53. Lowery, J. W. et al. The Role of BMP2 Signaling in the Skeleton. Crit. Rev. Eukaryot. Gene Expr. 21, 177-185 (2011).

54. Amthor, H., Christ, B., Weil, M. \& Patel, K. The importance of timing differentiation during limb muscle development. Curr. Biol. 8, 642-652 (1998).

55. Dahlqvist, C. et al. Functional Notch signaling is required for BMP4-induced inhibition of myogenic differentiation. Development 130, 6089-6099 (2003).

56. Wang, H. et al. Bmp signaling at the tips of skeletal muscles regulates the number of fetal muscle progenitors and satellite cells during development. Dev. Cell 18, 643-654 (2010).
57. Ono, Y. et al. BMP signalling permits population expansion by preventing premature myogenic differentiation in muscle satellite cells. Cell Death Differ. 18, 222-234 (2011).

58. Yin, H. et al. MicroRNA-133 controls brown adipose determination in skeletal muscle satellite cells by targeting Prdm16. Cell Metab. 17, 210-224 (2013).

59. Stuelsatz, P., Shearer, A. \& Yablonka-Reuveni, Z. Ancestral Myf5 gene activity in periocular connective tissue identifies a subset of fibro/adipogenic progenitors but does not connote a myogenic origin. Dev. Biol. 385, 366-379 (2013).

60. Snow, M. H. The effects of aging on satellite cells in skeletal muscles of mice and rats. Cell Tissue Res. 185, 399-408 (1977).

61. Schultz, E. Changes in the satellite cells of growing muscle following denervation. Anat. Rec. 190, 299-311 (1978).

62. Bosnakovski, D. et al. Prospective isolation of skeletal muscle stem cells with a Pax7 reporter. Stem Cell 26, 3194-3204 (2008).

63. Cerletti, M. et al. Highly efficient, functional engraftment of skeletal muscle stem cells in dystrophic muscles. Cell 134, 37-47 (2008).

64. Gilbert, P. M. et al. Substrate elasticity regulates skeletal muscle stem cell self-renewal in culture. Science 329, 1078-1081 (2010).

65. Epting, C. L. et al. Stem cell antigen-1 regulates the tempo of muscle repair through effects on proliferation of alpha7 integrin-expressing myoblasts. Exp. Cell Res. 314, 1125-1135 (2008).

66. Kafadar, K. A. et al. Sca-1 expression is required for efficient remodeling of the extracellular matrix during skeletal muscle regeneration. Dev. Biol. 326, 47-59 (2009).

67. Wu, M. P. \& Gussoni, E. Carbamylated erythropoietin does not alleviate signs of dystrophy in mdx mice. Muscle Nerve 43, 88-93 (2011).

68. Liadaki, K., Luth, E. S. \& Kunkel, L. M. Co-detection of GFP and dystrrophin in skeletal muscle tissue sections. BioTechniques 42, 699-700 (2007).

\section{Acknowledgements}

We thank the Dana Farber Hematologic Neoplasia Flow Cytometry Core for their outstanding services. We also thank Dr. Paul B. Yu for helpful discussions and for the pSmad 2 and pSmad 1,3 antibodies. The Pax7 antibody (DSHB, University of Iowa) was developed under the auspices of the NICHD. P.H. was supported by a Scientist Development Grant from AHA (0730285N). This work was supported by NIH/NINDS 2R01 NS047727 grant to E.G.

\section{Author contributions}

P.H. and E.G. planned most of the experiments and wrote the manuscript. P.H. performed most of the experiments. T.J.S. and A.B. performed some experiments and provided technical expertise; Y.-H.T. planned some of the experiments and contributed research material.

\section{Additional information}

Supplementary Information accompanies this paper at http://www.nature.com/ naturecommunications

Competing financial interests: The authors declare no competing financial interests.

Reprints and permission information is available online at http://npg.nature.com/ reprintsandpermissions/

How to cite this article: Huang, P. et al. Intramuscular adipogenesis is inhibited by myo-endothelial progenitors with functioning Bmprla signalling. Nat. Commun. 5:4063 doi: 10.1038/ncomms5063 (2014). 